\title{
A comparative study of the neural stem cell niche in the adult hypothalamus of human, mouse, rat and grey mouse lemur (Microcebus murinus)
}

Giuliana Pellegrino ${ }^{1,2}$, Claire Trubert ${ }^{1,2}$, Jérémy Terrien ${ }^{3}$, Fabien Pifferi ${ }^{3}$, Danièle Leroy ${ }^{1}$, Anne Loyens ${ }^{1}$, Martine Migaud ${ }^{4}$, Marc Baroncini ${ }^{1,2,5}$, Claude-Alain Maurage ${ }^{1,2,6}$, Christian Fontaine $^{2,7}$, Vincent Prévot ${ }^{1,2}$, Ariane Sharif ${ }^{1,2 *(D)}$

${ }^{1}$ Inserm, Jean-Pierre Aubert Research Center, Development and Plasticity of the Neuroendocrine Brain, Unit 1172, France; UDSL, School of Medicine, Place de Verdun, 59045 Lille Cedex, France.

${ }^{2}$ University of Lille, School of Medicine, Place de Verdun, 59045 Lille Cedex, France.

${ }^{3}$ MECADEV UMR 7179, Centre National de la Recherche Scientifique, Muséum National d'Histoire Naturelle, 91800 Brunoy, France.

${ }^{4}$ INRA, UMR 85 Physiologie de la Reproduction et des Comportements, Nouzilly, France; CNRS, UMR7247, Nouzilly, France; Université de Tours, Tours, France; Institut Français du Cheval et de l'Equitation (IFCE), Nouzilly, France.

${ }^{5}$ Department of Neurosurgery, Lille University Hospital, Lille, France.

${ }^{6}$ Department of Neuropathology, Lille University Hospital, Lille, France.

${ }^{7}$ Laboratory of Anatomy, Lille University Hospital, Lille, France.

Number of text pages: 30

Number of figures: 12

Number of tables: 4

Number of words (abstract): 249

Number of words: 8235

*Corresponding author: Ariane Sharif, Ph.D., Inserm U1172, Bâtiment Biserte, Place

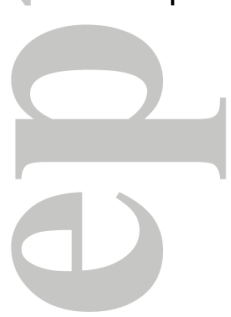
de Verdun, 59045 Lille Cedex, France

Tel: +33 3-20-62-20-65

Fax: +33 3-20-53-85-62

E-mail: ariane.sharif@inserm.fr

\section{Acknowledgments:}

This work was supported by a doctoral fellowship from the University of Lille to G.P., Inserm grant U1172, the Agence Nationale de la Recherche (ANR, France) ANR-15-CE14-0025 (to V.P.) and ANR-16-CE37-0006 (to M.M. and V.P.), the Association pour l'Etude des Anomalies Congénitales (to A.S.) and European Regional Development Fund (ERDF) attributed to Normandy region. We thank Elisabeth Wyart for her help with the immunolabeling of rat sections, Maurice De Meulaere (Laboratory of Anatomy, School of Medicine, Lille) for his skillful help during dissection of human brains and Philippe Chan Tchi Song from the PISSARO proteomic platform (Rouen) for mass spectrometry analysis.

This article has been accepted for publication and undergone full peer review but has not been through the copyediting, typesetting, pagination and proofreading process which may lead to differences between this version and the Version of Record. Please cite this article as an 'Accepted Article', doi: 10.1002/cne.24376

(C) 2017 Wiley Periodicals, Inc.

Received: J ul 05, 2017; Revised: Nov 08, 2017; Accepted: Nov 27, 2017 


\section{Abstract}

The adult brain contains niches of neural stem cells that continuously add new neurons to selected circuits throughout life. Two niches have been extensively studied in various mammalian species including humans, the subventricular zone of the lateral ventricles and the subgranular zone of the hippocampal dentate gyrus. Recently, studies conducted mainly in rodents have identified a third neurogenic niche in the adult hypothalamus. In order to evaluate whether a neural stem cell niche also exists in the adult hypothalamus in humans, we performed multiple immunofluorescence labeling to assess the expression of a panel of neural stem/progenitor cell (NPC) markers (Sox2, nestin, vimentin, GLAST, GFAP) in the human hypothalamus and compared them with the mouse, rat and a non-human primate species, the grey mouse lemur (Microcebus murinus). Our results show that the adult human hypothalamus contains four distinct populations of cells that express the five NPC markers: i) a ribbon of small stellate cells that lines the third ventricular wall behind a hypocellular gap, similar to that found along the lateral ventricles, ii) ependymal cells, iii) tanycytes, which line the floor of the third ventricle in the tuberal region, and iv) a population of small stellate cells in the suprachiasmatic nucleus. In the mouse, rat and mouse lemur hypothalamus, coexpression of NPC markers is primarily restricted to tanycytes, and these species lack a ventricular ribbon. Our work thus identifies four cell populations with the antigenic profile of NPCs in the adult human hypothalamus, of which three appear specific to humans.

Key Words: humans; hypothalamus; neural stem cells; adult; third ventricle; tanycyte; RRID:RGD_1566457; RRID:IMSR_JAX:000664; RRID:AB_2286684; RRID:AB_2251304; RRID:AB_94911; $\quad$ RRID:AB_10015203; $\quad$ RRID:AB_11212377; $\quad$ RRID:AB_10013382; RRID:AB_94844; $\quad$ RRID:AB_304334; $\quad$ RRID:AB_4443209; $\quad$ RRID:AB_2314148;

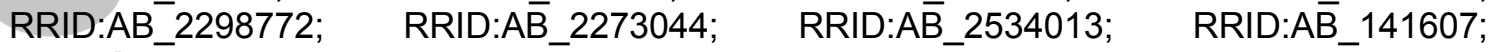
RRID:AB_2534017; RRID:AB_141708; RRID:AB_142581; RRID:AB_141844; RRID:AB_2340375; RRID:AB_2651133; RRID:SCR_0141999; RRID:SCR_010285

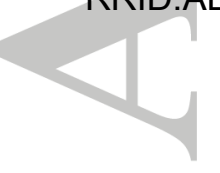




\section{Introduction}

Neural stem cells persist in the brain of vertebrates beyond development (Doetsch, 2003). In adult mammals, the two best-described neural stem cell niches are the subventricular zone $(S V Z)$ that lines the wall of the lateral ventricles, and the subgranular zone (SGZ) at the base of the hippocampal dentate gyrus (Alvarez-Buylla \& Lim, 2004; Ming \& Song, 2005). These niches harbor neural stem cells that self-renew throughout life and generate new neurons and glial cells that are functionally integrated into selected circuits and participate in specific brain functions such as learning, memory and odor discrimination (Gonçalves, Schafer, \& Gage, 2016; Lledo \& Valley, 2016). Almost two decades ago, a study performed in the golden hamster reported for the first time the generation of new neurons in the adult hypothalamus (Huang, DeVries, \& Bittman, 1998), a small diencephalic region surrounding the third ventricle and involved in the control of vital processes such as energy metabolism, reproduction, biological rhythms and other homeostatic processes. Since then, a number of studies have accumulated suggesting that neurons and glial cells are generated from local neural stem/progenitor cells (NPCs) in the hypothalamus throughout life (Batailler et al., 2014; Chaker et al., 2016; Gouazé et al., 2013; Haan et al., 2013; Jourdon et al., 2015; Kokoeva, Yin, \& Flier, 2005, 2007; Lee et al., 2012; Li, Tang, \& Cai, 2012; McNay, Briançon, Kokoeva, Maratos-Flier, \& Flier, 2012; Pencea, Bingaman, Wiegand, \& Luskin, 2001; PérezMartín et al., 2010; Pierce \& Xu, 2010; S. C. Robins et al., 2013; Sarah C. Robins et al., 2013). Hypothalamic NPCs are regulated by various physiological factors and pathophysiological conditions (Rojczyk-Gołębiewska, Pałasz, \& Wiaderkiewicz, 2014; Sharif, Ojeda, \& Prevot, 2014), and hypothalamic neurogenesis, while it occurs at a lower rate than in the two classic niches (Migaud et al., 2010), has functional significance for the control of energy metabolism (Djogo et al., 2016; Gouazé et al., 2013; Kokoeva et al., 2005; Lee et al., 2012, 2014; Li et al., 2012; Li, Tang, Purkayastha, Yan, \& Cai, 2014; Pierce \& Xu, 2010).

Several different, and non-exclusive, hypotheses have been proposed concerning the 
identity and location of hypothalamic NPCs: some studies suggest that they reside within the hypothalamic parenchyma (Kokoeva et al., 2007; Li et al., 2012; Sarah C. Robins et al., 2013), some that they are subependymal astrocytes located in a region of the mid third ventricle (Pérez-Martín et al., 2010), and others that they are a subpopulation of tanycytes, ependymoglial cells that line the ventral portion of the third ventricle (Chaker et al., 2016; Haan et al., 2013; Jourdon et al., 2015; Lee et al., 2012; S. C. Robins et al., 2013).

Most of our knowledge of adult neural stem and progenitor cells comes from rodent models, and few studies have been conducted in humans. Neuroanatomical studies and the recently developed technique of ${ }^{14} \mathrm{C}$ dating have confirmed that cells exhibiting neural stem cell properties and neurogenesis persist in the adult human brain (Bergmann, Spalding, \& Frisén, 2015). While the hippocampal neurogenic system in adult humans exhibits features similar to that of rodents, i.e. the local generation of dentate granule neurons from nearby neural stem cells (Eriksson et al., 1998; Ernst et al., 2014; Knoth et al., 2010; Spalding et al., 2013), the SVZ neurogenic system appears to differ significantly between human and rodents. Not only does the cellular organization of the niche differ (Quiñones-Hinojosa et al., 2006; Sanai et al., 2004), but newborn neurons adopt a different fate, migrating into the adjacent striatum to become medium spiny neurons (Ernst et al., 2014) instead of migrating long distances along the rostral migratory stream to become part of the olfactory bulb circuit (Bergmann et al., 2012) as in rodents (Ming \& Song, 2005).

A recent neuroanatomical study has revealed the presence of cells expressing the neuroblast marker doublecortin (DCX) in the adult human hypothalamus (Batailler et al., 2014), raising the possibility that neurogenesis, and a neural stem cell niche, may exist in this region in humans. While the expression of the NPC markers nestin and vimentin has been reported in the adult human hypothalamus (Baroncini et al., 2007; Dahiya, Lee, \& Gutmann, 2011; Nogueira et al., 2014), there has been no detailed mapping of the expression of a repertoire of NPC markers in the adult human hypothalamus as yet.

Here, we carried out a neuroanatomical characterization of the expression of a combination of NPC markers in the adult human hypothalamus, along with the SVZ and 
SGZ. To evaluate potential inter-species variability, the expression of NPC markers in the adult hypothalamus was concomitantly analyzed in the mouse, rat and a non-human primate species, the grey mouse lemur (Microcebus murinus).

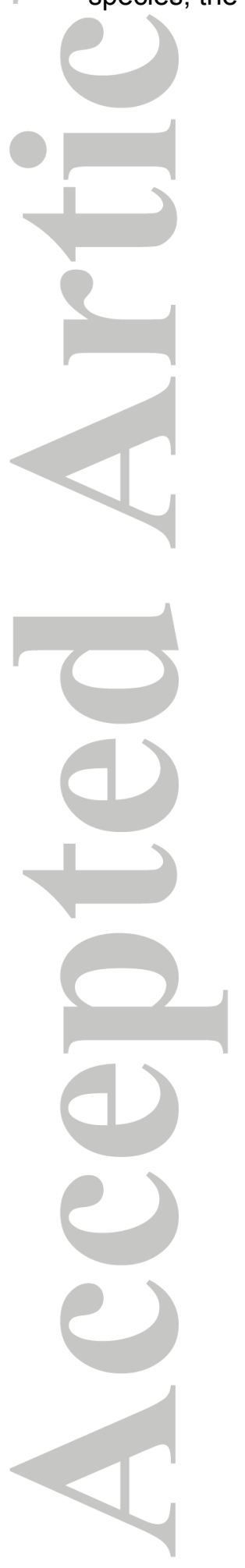




\section{Materials and methods}

\section{Tissue}

Human

Tissues were made available in accordance with French bylaws (Good Practice Concerning the Conservation, Transformation and Transportation of Human Tissue to be Used Therapeutically, published on December 29, 1998). Permission to use human tissues was obtained from the French Agency for Biomedical Research (Agence de la Biomédecine, Saint-Denis la Plaine, France, protocol no. PFS16-002).

A total of nine brains were obtained from autopsies (average age 81 years, range 60 92 years; average postmortem delay 23 hours, range $8-41.5$ hours). The brain samples were taken from patients that donated bodies to Science in compliance with the French laws on bioethics. Structures were identified by reference to an atlas of the human brain (Mai, Paxinos, \& Voss, 2008).

One 11-week old (menstrual age) human fetus was obtained after elective abortion from the Gynaecology Department of the University Hospital of Lille. Written informed consent had been previously obtained from the parent.

One de novo glioblastoma multiforme (GBM) sample was obtained from the Neurosurgery Clinic of the University Hospital of Lille. The GBM specimen was obtained at initial surgery of a 65-year old male. The tumor was classified and graded by a neuropathologist according to the World Health Organization system (Louis et al., 2007). Written informed consent had been previously obtained from the patient and/or his family members. The tissue was processed as described previously (Duhem-Tonnelle et al., 2010).

\section{Rodents}

Animal studies were approved by the Institutional Ethics Committee for the Care and Use of Experimental Animals of the University of Lille; all experiments were performed in 
accordance with the guidelines for animal use specified by the European Union Council Directive of September 22, 2010 (2010/63/EU). Tissues were obtained from 7 adult female Sprague-Dawley rats (2-3 months, Janvier Laboratories, Saint Berthevin, France; RRID:RGD_1566457) and 3 adult C57BL/6J female mice (3-4 months, Charles River, L'Arbresle, France; RRID:IMSR_JAX:000664). The animals were maintained on a 12-hour light/12-hour dark cycle (lights on at $07.00 \mathrm{~h}$ ), with food and water available ad libitum.

\section{Grey mouse lemur (Microcebus murinus)}

Tissues were obtained from one male (1.9 year-old) and one female (5.9 year-old) grey mouse lemur (Microcebus murinus) bred in the laboratory breeding colony of Brunoy (MNHN, France, license approval $N^{\circ}$ A91.114.1). The two animals were sacrificed during the long day period (14-hours of light/day), which corresponds to the period of reproductive activity. Mouse lemur studies were approved by the Cuvier Ethics Committee for the Care and Use of Experimental Animals of the Muséum National d'Histoire Naturelle ( $\mathrm{n}^{\circ} 2083-$ 2015090311335786).

\section{Fluorescent immunostaining}

\section{Human}

After whole brain removal, blocks of $20 \mathrm{~mm}$ per side encompassing the hypothalamus were harvested with the optic chiasm as the anterior limit and the mammillary bodies as the posterior limit. The hippocampus was collected from a cut posterior to the mammillary bodies. The dorso-lateral and ventral walls of the body of the lateral ventricles were collected on a width of about $5 \mathrm{~mm}$ towards the parenchyma. Tissue blocks were immersion fixed in $4 \%$ paraformaldehyde in $0.1 \mathrm{M}$ phosphate buffer $(\mathrm{PB})(\mathrm{pH} 7.4)$ for 1 week at $4^{\circ} \mathrm{C}$, cryoprotected in PB containing $0.9 \%$ sodium chloride (PBS) and sucrose at $10 \%$ for 48 hours followed by $20 \%$ for 3 days, embedded in Tissue Tek® (Sakura Finetek, Villeneuve d'Ascq, France) and frozen in isopentane cooled with liquid nitrogen. Coronal cryostat sections (14 or $20 \mu \mathrm{m}$ ) were mounted on chrome-alum-gelatin coated slides, air-dried, and subjected to 
immunofluorescent stainings. After rehydration in a solution of sodium citrate $0.01 \mathrm{M}(\mathrm{pH} 6)$ (citrate buffer), the sections were subjected to microwave pretreatment in citrate buffer for 4 minutes at $800 \mathrm{~W}$ followed by 2 cycles 4 minutes each at $400 \mathrm{~W}$ for antigen retrieval. After cooling at room temperature and washing in $\mathrm{PB}$, sections were incubated for 15 minutes in PBS containing $0.3 \%$ Triton $\mathrm{X}-100$ and $2 \%$ normal donkey serum (PBSTS) at room temperature to block the nonspecific sites. Sections were then incubated with primary antibodies diluted in PBSTS for one to two nights at $4^{\circ} \mathrm{C}$ in a humid chamber. The characteristics of the primary antibodies used are provided in Table 1. After rinsing in PB, secondary antibodies diluted in PBSTS were deposited on sections and incubated at room temperature for 1 hour. The characteristics of the secondary antibodies used are provided in Table 2. After washing in PB, cell nuclei were stained with Hoechst 33258 bis-Benzimide (Molecular Probes, Eugene, OR, USA; RRID:AB_2651133) diluted at 1/1000 in PB for 2 minutes and then washed in PB. To avoid the strong autofluorescence caused by lipofuscin granules usually present in adult human brain tissue, sections were immersed in a solution of 0.3\% Sudan Black B (Sigma, St Quentin Fallavier, France) in $70 \%$ ethanol for 5 minutes (Romijn et al., 1999). This treatment completely blocked autofluorescence. After washing in $\mathrm{PB}$, sections were coverslipped in Mowiol mounting medium (20\% Mowiol, $2.5 \%$ DABCO in

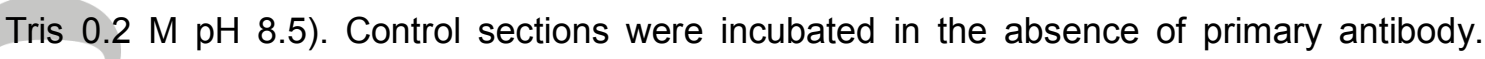
Omission of the primary antibody resulted in no staining.

The human fetus was immersion fixed in $4 \%$ paraformaldehyde for 4 days at $4^{\circ} \mathrm{C}$, cryoprotected in $30 \%$ sucrose/PBS overnight at $4^{\circ} \mathrm{C}$, and then processed and subjected to immunofluorescent stainings as described above.

\section{Rat}

Animals were anesthetized by intraperitoneal injection of pentobarbital $(70 \mathrm{mg} / \mathrm{kg})$. They were perfused transcardially with a rinse of saline solution $(0.9 \% \mathrm{NaCl})$, followed by $500 \mathrm{ml}$ of $4 \%$ paraformaldehyde in $0.1 \mathrm{M} \mathrm{PB}(\mathrm{pH} 7.4)$. The brains were removed and immersed in the same fixative for $2-3$ hours at $4^{\circ} \mathrm{C}$. They were then transferred to PB containing $20 \%$ 
sucrose until they had sunk, embedded in Tissue Tek® (Sakura Finetek, Villeneuve d'Ascq, France), and frozen in liquid nitrogen. Frozen $14-\mu \mathrm{m}$ coronal sections were prepared using a cryostat (CM3050, Leica) and collected throughout the full extent of the third ventricle. The sections were mounted onto chrome-alum-gelatin coated slides, air-dried and subjected to immunofluorescent stainings as described above. Anatomical landmarks were determined using the rat brain atlas of Swanson (Swanson, 2004).

\section{Mouse}

Animals were anesthetized by intraperitoneal injection of xylazine $10 \mathrm{mg} / \mathrm{kg}$ (Rompun 2\%, Bayer) and ketamine $200 \mathrm{mg} / \mathrm{kg}$ (Ketalar, Parke-Davis), perfused transcardially with a rinse of saline solution, followed by $100 \mathrm{ml}$ of $4 \%$ paraformaldehyde in $0.1 \mathrm{M} \mathrm{PB}(\mathrm{pH} 7.4)$. After brain removal, post-fixation and freezing, $30 \mu \mathrm{m}$ free-floating coronal sections encompassing the full extent of the third ventricle were prepared using a cryostat and collected in ice-cold PB. Free-floating sections were subjected to immunofluorescent stainings following the above-described procedure, mounted on chrome-alum-gelatin coated slides, air-dried and coverslipped in Mowiol mounting medium. Anatomical landmarks were determined using the mouse brain atlas from Paxinos and Franklin (Paxinos \& Franklin, 2001).

\section{Grey mouse lemur (Microcebus murinus)}

Animals were anesthetized by intraperitoneal injection of pentobarbital $5 \mathrm{mg} / \mathrm{kg}$, perfused transcardially with a rinse of saline solution, followed by $120 \mathrm{ml}$ of $4 \%$ paraformaldehyde in 0.1 M PB ( $\mathrm{pH} 7.4$ ). After brain removal, post-fixation and freezing, frozen 14- $\mu \mathrm{m}$ coronal sections were prepared using a cryostat and collected throughout the full extent of the third ventricle. The sections were mounted onto chrome-alum-gelatin coated slides, air-dried and subjected to immunofluorescent stainings as described above. Anatomical landmarks were determined using the Microcebus murinus brain atlas of Bons (Bons, Silhol, Barbié, MestreFrancés, \& Albe-Fessard, 1998). 


\section{Antibody characterization}

Human

We used human fetal cerebral cortex and GBM as positive control tissues to verify the specificity of primary antibodies in human tissues.

In the fetal cerebral cortex, the SRY (sex determining region Y)-box 2 (Sox2) antibody (goat polyclonal \# sc-17320 from Santa Cruz) yielded a nuclear staining with decreasing density from the ventricular to the pial surface (Fig. 1a), as reported by others (Vinci et al., 2016). This antibody detects a single band of $34 \mathrm{kDa}$ on Western blots of human neural progenitor and GBM stem-like cell lysates (Guichet et al., 2013). Moreover, immunoreactivity is lost when human embryonic stem cells are treated with a small interfering RNA (siRNA) directed against Sox2 (Adachi, Suemori, Yasuda, Nakatsuji, \& Kawase, 2010). In the adult hypothalamus, a double labeling with another Sox2 antibody (mouse monoclonal \# ab79351 from Abcam, 1/300; RRID:AB_10710406) showed an overlap of the two stainings (Fig. 1i, j). In agreement with previous reports, the nestin antibody stained radial glial cells in the fetal cerebral cortex (Fig. 1e) (Vinci et al., 2016), tumoral cells in the GBM specimen (Fig. 1h) (Ludwig \& Kornblum, 2017) and hypothalamic adult tanycytes (Fig. 6) (Baroncini et al., 2007). This antibody detects a band at $177 \mathrm{kDa}$, the expected molecular weight, on Western blots of human GBM stem-like cell lysates (Ciechomska, Przanowski, Jackl, Wojtas, \& Kaminska, 2016). Moreover, inhibition of nestin expression using short hairpin RNA or siRNA transfection in a human lung adenocarcinoma cell line results in decreased immunolabeling (Narita et al., 2014).

Vimentin was detected in radial glial cells in the fetal cerebral cortex (Fig. 1c), as described elsewhere (Howard, Chen, \& Zecevic, 2006; Vinci et al., 2016). It was strongly expressed in adult tanycytes (Fig. 6b) in agreement with other reports (Baroncini et al., 2007; Koopman, Taziaux, \& Bakker, 2017). The M0725 antibody from Dako detects a band at 54 kDa on Western blots of human mesenchymal stromal cell lysates (Talele, Fradette, Davies, Kapus, \& Hinz, 2015). Treatment of a human cholangiocarcinoma cell line with siRNA 
against vimentin suppressed immunoblot and immunofluorescent signals with this antibody (Saentaweesuk et al., 2017). The two anti-vimentin antibodies used yielded a similar expression profile.

We had previously used the Glial Fibrillary Acidic Protein (GFAP) antibody (rabbit polyclonal Z0334 from Dako) to stain cerebro-cortical (Duhem-Tonnelle et al., 2010) and hypothalamic (Baroncini et al., 2007) astrocytes in the adult human brain, and tumoral cells and reactive astrocytes in human GBM (Duhem-Tonnelle et al., 2010). This antibody stained radial glial cells in the fetal cerebral cortex (Fig. 1f, g), as described by others (Howard et al., 2006) and it detects a single band at $50 \mathrm{kDa}$ on Western blots of human GBM cell lysates (Tardito et al., 2015). A co-immunolabeling with another anti-GFAP antibody (mouse monoclonal MAB3402 from Chemicon) previously used by others to stain the ribbon of SVZ astrocytes (Quiñones-Hinojosa et al., 2006; Sanai et al., 2004) yielded a strict co-localization (Fig. 1k, I). The expression profile observed with the two antibodies along the lateral ventricles replicates the pattern of mRNA expression determined by in situ hybridization (Allen brain atlas; http://human.brain-map.org/ish/experiment/show/159107343), with a labeling of ependymal, subependymal and small parenchymal cells.

The Glutamate-Aspartate Transporter (GLAST) antibody labeled radial glial cells in the fetal cerebral cortex (Fig. 1d) following an expression profile described elsewhere (Howard et al., 2006). The expression profile observed along the lateral ventricles replicates the pattern of mRNA expression determined by in situ hybridization, with a strong enrichment in ependymal and ribbon cells, as well as scattered parenchymal cells (Allen brain atlas; http://human.brain-map.org/ish/experiment/show/160133315). This antibody detects a single band at $65 \mathrm{kDa}$ on Western blots of human cerebrocortical homogenates (Roberts, Roche, \& McCullumsmith, 2014). Based on liquid chromatography coupled to tandem mass spectrometry (LC-MS/MS), we determined the GLAST immunogen peptide (ab127026, Abcam) sequence to be from amino acid 522-541 (data not shown).

The Ki67 antibody has been used previously to stain proliferative cells in human GBM (Duhem-Tonnelle et al., 2010). It yielded a dense nuclear staining in the fetal cerebral cortex 
following a gradient with the highest density of positive cells in the ventricular and subventricular zones (Fig. 1b), as described elsewhere (Bayatti et al., 2008; Harkin et al., 2016). In the adult human brain, the Ki67 antibody produced a patchy staining in the nucleus of cells, some of which exhibited mitotic figures (Fig. 8). This antibody detects a band at 360 kDa on Western blots of primary human dermal fibroblast cell lysates (Chierico et al., 2017). The immunoblot signal is lost following siRNA-mediated knock-down of Ki67 in various human cell lines (Sun et al., 2017).

The Neuronal Nuclei (NeuN) antibody has been used previously to stain mature neurons in the adult human cerebral cortex (Duhem-Tonnelle et al., 2010) and hippocampus (Knoth et al., 2010). This antibody detects a doublet at 46-50 kDa, the expected apparent molecular weight, in Western blots of human hippocampus autopsy homogenates (Engel et al., 2011).

The Vasoactive intestinal peptide (VIP) antibody has been used previously to immunostain neurons in the monkey and human enteric nervous system (Noorian, Taylor, Annerino, \& Greene, 2011) and produced a staining pattern in the suprachiasmatic nucleus (Fig. 7a) similar to that described in the literature with other antibodies (Hofman, Zhou, \& Swaab, 1996; Wang et al., 2015) or using in situ hybridization (van Wamelen et al., 2013).

The CD68 antibody has been used previously by others to stain microglia in the human brain (Monier, Evrard, Gressens, \& Verney, 2006). As expected for a lysosomal membrane protein, it yielded a cytoplasmic punctuate staining (Fig. 8g). This antibody detects bands at 110, 70, $40 \mathrm{kDa}$ in Western blots of human lung, spleen and U937 monocytic cell line extracts using reducing conditions. An additional band is detected at $220 \mathrm{kDa}$ in spleen extracts using non-reducing conditions (Pulford et al., 1989).

\section{Rodent}

The Sox2 antibody (goat polyclonal \# sc-17320 from Santa Cruz) yielded a strong staining in the SVZ (not shown) and in the hypothalamus (Fig. 9a, e, i, Fig. 10a, e) that recapitulated expression patterns previously described with other antibodies in the mouse (Haan et al., 
2013; Li et al., 2012) and rat (Bennett, Yang, Enikolopov, \& lacovitti, 2009; Hoefflin \& Carter, 2014). It also replicates the pattern of mRNA expression determined by in situ hybridization in the adult mouse brain (Allen brain atlas; http://mouse.brainmap.org/experiment/show/77280331). This antibody detects a single band at $34 \mathrm{kDa}$ in Western blots of mouse embryonic stem cell lysates (manufacturer's technical information). Moreover, it yields an immunostaining in a mouse mesenchymal stem cell line stably overexpressing Sox 2 by retroviral infection while no staining is observed in non-infected cells (Ding et al., 2012).

The nestin antibody stained tanycytes and capillaries (Fig. 9b, f, j, Fig. 10f), as previously reported in the mouse (Alliot, Rutin, Leenen, \& Pessac, 1999; Haan et al., 2013; Lee et al., 2012) and rat (Bennett et al., 2009; Takamori et al., 2009). This expression profile replicates the pattern of mRNA expression determined by in situ hybridization in the adult mouse brain (Allen brain atlas; http://mouse.brain-map.org/experiment/show/1387). This antibody detects a doublet in the $200-220 \mathrm{kDa}$ range on Western blots of rat brain homogenates (Shigemoto-Mogami, Hoshikawa, Goldman, Sekino, \& Sato, 2014). Moreover, rat cardiac ventricular fibroblasts infected with a lentivirus containing a shRNAmir directed against nestin show reduced immunocytofluorescent and immunoblot signals (Béguin, Gosselin, Mamarbachi, \& Calderone, 2012).

Vimentin was detected in ependymal cells, tanycytes and capillaries (Fig. 9c, g, inset in j, Fig. 10b, h), as previously reported in the mouse (Langlet, Mullier, Bouret, Prevot, \& Dehouck, 2013; Mullier, Bouret, Prevot, \& Dehouck, 2010) and rat (Pérez-Martín et al., 2010). The two anti-vimentin antibodies used yielded a similar expression profile. This expression profile replicates the pattern of mRNA expression determined by in situ hybridization in the adult mouse (Allen brain atlas; http://mouse.brainmap.org/experiment/show/79907904) and rat brain (Helfer et al., 2016). The Dako antibody detects a single band at $54 \mathrm{kDa}$ on Western blots of rat hepatic stellate cell lysates (Mezaki et al., 2013). 


\section{Microcebus murinus}

The specificity of the Sox 2 and vimentin antibodies was inferred from the similarity in the expression pattern with rodents. Noteworthy, we tested 2 anti-nestin antibodies, MAB1259 from R\&D Systems and MAB353 clone rat-401 from Millipore, recognizing human and rodent nestin, respectively, but none of them yielded any staining in the grey mouse lemur.

\section{Histological staining}

For anatomical identification of hypothalamic regions and nuclei, coronal cryostat sections were immersed in a solution of Toluidine Blue dissolved at $0.5 \%$ in a solution of $1 \%$ sodium borate for 6 minutes at room temperature. After three rinses in water, sections were dehydrated in successive alcoholic solutions: 2 times 5 minutes in ethanol $70^{\circ}, 7$ minutes in ethanol $70^{\circ}$ containing $0.2 \%$ acetic acid, 2 times 5 minutes in ethanol $100^{\circ}$ and 2 times 3 minutes in xylene. Sections were coverslipped in Eukitt mounting medium (Sigma).

\section{Microscopy}

Analysis of sections and acquisition of images were done using an Axio Imager Z2 ApoTome microscope equipped with a motorized stage (Zeiss, Germany) and an ORCA-Flash 4.0 V2 camera (Hamamatsu, Japan) driven by the Zen imaging software (Zeiss). Specific filter cubes were used for the visualization of green (Alexa 488 fluorochrome) (Excitation wavelength: $475 / 40 \mathrm{~nm}$, beam splitter: $500 \mathrm{~nm}$, emission wavelength: 530/50 nm), red (Alexa 568 fluorochrome) (excitation wavelength: $550 / 25 \mathrm{~nm}$, beam splitter: $570 \mathrm{~nm}$, emission wavelength: 605/70 nm), far red (Alexa 647 fluorochrome) (excitation wavelength: 640/30 $\mathrm{nm}$, beam splitter: $660 \mathrm{~nm}$, emission wavelength: 690/50 nm) and blue fluorescence (Hoechst) (excitation wavelength: $365 \mathrm{~nm}$, beam splitter: $395 \mathrm{~nm}$, emission wavelength: $445 / 50 \mathrm{~nm}$ ). High magnification photomicrographs represent maximal intensity projections derived from 15-52 triple or quadruple-ApoTome images collected using the z-stack module of the Zen imaging software and a Zeiss 20x (numerical aperture NA $=0.8$ ) or $40 x$ objective $(N A=0.75)$. All images were captured in a stepwise fashion over a defined $z$-focus range 
corresponding to all visible fluorescence within the section and consistent with the optimum step size for the corresponding objective and the wavelength $(500 \mathrm{~nm})$. To create photomontages, ApoTome images were captured using the z-stack module coupled to the MosaiX module of the Zen imaging software and a Zeiss $5 x(N A=0.15)$ or $20 x$ objective for each filter sequentially. Images to be used for figures were pseudocolored, adjusted for brightness and contrast and merged using Photoshop (Adobe Systems, San Jose, CA; RRID:SCR_014199).

\section{Analysis}

\section{Human}

Co-expression of nestin and Sox2 was systematically analyzed on sections distributed across the antero-posterior extent of seven hypothalami. Then, triple stainings for nestin/Sox2/vimentin, nestin/Sox2/GLAST, nestin/Sox2/GFAP, nestin/Sox2/Ki67 and vimentin/Sox2/NeuN were performed on representative sections. Double and triple immunostainings were performed on a total of $73 \pm 6$ (mean \pm SEM) (range, $47-94)$ sections per specimen.

Quantification of stainings in the hypothalamic ependymal layer, ribbon cells and buds was performed on the seven specimens. A total of $2044 \pm 226$ (mean \pm SEM) ependymal cells, $2117 \pm 423$ (mean \pm SEM) ribbon cells and $836 \pm 260$ (mean \pm SEM) bud cells were counted per specimen. Noteworthy, the border of the third ventricle was usually less well preserved at its floor, where tanycyte cell bodies are found, thus precluding the quantification of stainings in this cell type. Quantification of stainings in the suprachiasmatic nucleus was made on three hypothalami. While the rodent suprachiasmatic nucleus appears as a high cell density spherical structure clearly delimited after counterstaining for cell nuclei, it is not the case in the human. The localisation of the human suprachiasmatic nucleus was determined using an atlas (Mai et al., 2008) and further verified by an immunostaining for VIP, which is produced by a subpopulation of suprachiasmatic neurons (Hofman et al., 1996). For 
quantitative analysis of the stainings, a total of $2931 \pm 235$ (mean \pm SEM) cells were counted on five to seven sections per suprachiasmatic nucleus.

Expression of NPC markers in the dentate gyrus of the hippocampus was analyzed on specimens collected from three brains. Double and triple immunostainings were performed on a total of $20 \pm 4$ (mean \pm SEM) (range, $12-26$ ) sections per specimen.

The SVZ was analysed on samples collected from six brains. Three samples were collected in the dorsal portion of the body of the lateral ventricle, 4 in its ventral portion and 3 in the temporal horn. Notably, three ventral SVZ samples were present in the tissue block containing the third ventricle, enabling comparison between these regions on the same sections. Double and triple immunostainings were performed on a total of $33 \pm 10$ (mean \pm SEM) (range, 12 - 94) sections per specimen.

\section{Rat}

Co-immunolabelings of nestin, Sox2 and vimentin were performed and analysed on 42-204 sections per animal regularly spaced between plate 17 (i.e. the anterior-most part of the third ventricle above the optic chiasm) and plate 38 (i.e., posterior-most part of the third ventricle and end of mammillary nuclei) of the rat brain atlas from Swanson (Swanson, 2004).

\section{Mouse}

Triple nestin/Sox2/vimentin immunostainings were performed and analysed on 9-12 sections per animal regularly spaced between plate 34 (i.e. a region containing the optic chiasm and the anterior part of the suprachiasmatic nucleus) and plate 53 (i.e., posterior-most part of the third ventricle and mammillary nuclei) of the mouse brain atlas from Paxinos and Franklin (Paxinos \& Franklin, 2001).

\section{Microcebus murinus}


Co-expression of vimentin and Sox2 was analysed on the male and female specimens on a total of 78 and 60 sections, respectively, encompassing the rostro-caudal extent of the third ventricle, i.e. plate 39 to 51 of the Microcebus murinus brain atlas of Bons (Bons et al., 1998).

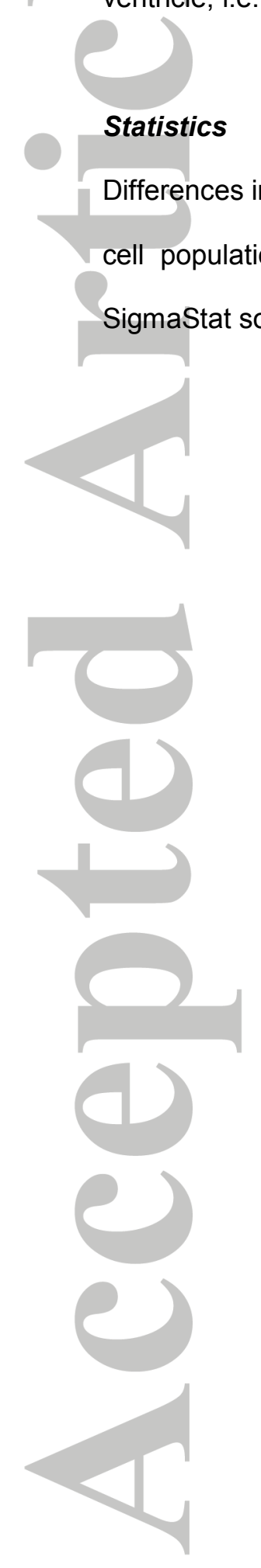




\section{Results}

\section{The human hypothalamus}

For the neuroanatomical analysis, the hypothalamus was antero-caudally subdivided into four regions: the anterior-most region surrounding the preoptic recess (Fig. 2a), the anterior hypothalamic area containing the optic chiasm, the anterior commissure, the paraventricular and supraoptic nuclei (Fig. 2b), the tuberal region containing the ventromedial, dorsomedial, infundibular nuclei and the median eminence (Fig. 2c, d), and the mammillary region containing the mammillary bodies and the posterior hypothalamic nucleus (Fig. 2e) (Mai et al., 2008).

In order to identify putative NPCs, we first mapped the co-expression of the NPC markers nestin and Sox2 in the whole hypothalamus (Fig. 3) and then performed triple stainings for nestin, Sox2 and vimentin, GLAST or GFAP in representative regions (Fig. 4, 5, 6, 7 and Table 3). A similar expression profile was found in the seven hypothalami analyzed. Expression of nestin and Sox2 was primarily detected in a region bordering the third ventricle (Fig. 3). Deeper in the parenchyma, labeling for Sox2 was absent while labeling for nestin was only seen in capillary vessels (Fig. 3, asterisks). Ependymal cells, which line the ventricle, showed intense Sox2 (Fig. 3, 4), low to high vimentin (Fig. 4a, c) and intense GLAST (Fig. 4h, j) immunoreactivity in their vast majority, while expression of nestin (Fig. 4b, i, p) and GFAP (Fig. 4o, q) was less ubiquitously detected (Table 3). Co-expression of nestin and Sox2 was detected in $32.1 \pm 4.0 \%$ of ependymal cells. Among the population of nestin/Sox2 co-expressing ependymal cells, $96.8 \pm 1.4 \%$ expressed vimentin, $98.9 \pm 0.3 \%$ expressed GLAST and $81.1 \pm 7.1 \%$ expressed GFAP, implying that at least $77 \%$ of nestin/Sox2-positive cells also expressed vimentin, GLAST and GFAP. Ependymal cells often invaginated into the underlying parenchyma to form crowns (Fig. 3f) or rosettes (Fig. $3 b-e)$. Heterogeneity in the antigenic profile and organization of ependymal cells was not specific to a particular area of the third ventricle. 
A ribbon of small process-bearing cells expressing nestin, Sox2, vimentin, GLAST and GFAP consistently lined the border of the ventricle, separated from it by a hypocellular gap (Fig. $3 a_{1}, a_{3}, b, c, d$, Fig. 4a, h, o, table 3). The ribbon was variable in thickness, from one (Fig. $3 a_{1}$ ) to multiple cell layers (Fig. $3 a_{3}$ ), as well as the gap that ranged from $\sim 20 \mu \mathrm{m}$ (Fig. $3 \mathrm{a}_{1}$ ) to $\sim 100-150 \mu \mathrm{m}$ (Fig. $3 \mathrm{~d}$ ). Noteworthy, the hypocellular gap was consistently at its largest extent in the mammillary region (Fig. 3d). Co-expression of nestin and Sox2 was detected in $18.0 \pm 3.7 \%$ of ribbon cells. Nestin/Sox 2 co-expressing ribbon cells frequently sent long processes contacting the ependymal layer (Fig. 3b, inset) and/or capillaries (Fig. $3 g$ ). Triple co-immunolabelings showed that nestin/Sox2 co-expressing ribbon cells also expressed vimentin (Fig. 4e-g), GLAST (Fig. 4I-n) and GFAP (Fig. 4s-u) in $83.8 \pm 4.7 \%, 87.7$ $\pm 4.2 \%$ and $80.9 \pm 9.4 \%$ of them, respectively, implying that at least $52 \%$ of nestin/Sox $2-$ positive cells also express vimentin, GLAST and GFAP. The hypocellular gap contained nestin- and vimentin-expressing processes (Fig. 3 and 4), presumably corresponding to ependymal and/or ribbon cell processes, and was enriched in GLAST (Fig. 4h) and GFAP (Fig. 40) immunoreactivity. The gap and ribbon were devoid of NeuN-immunoreactive neurons. NeuN-immunoreactive cells were primarily found in the parenchyma at distance from the subependymal region (not shown) and occasionally in the proximal parenchyma underlying the subependymal region (Fig. 5j-I).

Notably, some portions of the third ventricular wall were devoid of the gap-and-ribbon organization but exhibited a thick border enriched in intermingled nestin/Sox2-positive cells (Fig. $\left.3 a_{2}\right)$ sometimes bulging into the ventricle (Fig. $\left.3 a_{4}, g, h\right)$ and showing systematic interruption of the ependymal layer. These buds were highly variable in size and shape, from long and flat (Fig. $\left.3 a_{2}, a_{4}\right)$ to ovoid and protuberant (Fig. 3g, h), with frequent strengthening in nestin staining (Fig. 3h). They contained a rich network of NPC marker-expressing cells (Table 3) but were devoid of NeuN-immunoreactive cells (Fig. $5 j-1$ ). Co-expression of nestin and Sox 2 was detected in $46.8 \pm 5.5 \%$ of bud cells. Among the population of nestin/Sox2 coexpressing cells, $72.3 \pm 7.8 \%$ expressed vimentin (Fig. $5 \mathrm{a}-\mathrm{C}$ ), $98.5 \pm 1.3 \%$ expressed GLAST 
(Fig. $5 d-$ f) and $95.5 \pm 2.1 \%$ expressed GFAP (Fig. $5 g-i$ ), implying that at least $66 \%$ of nestin/Sox2-positive cells also express vimentin, GLAST and GFAP. These structures were found anywhere along the ventricular wall of all hypothalami examined.

In the tuberal region, the floor of the third ventricle does not exhibit the gap-and-ribbon organization and is lined by tanycytes whose processes extend into the median eminence (Fig. 6a). Co-immunolabelings showed that Sox2, nestin, vimentin, GLAST and GFAP were expressed by tanycytes (Fig. 6). While nestin and vimentin, GLAST or GFAP were frequently co-expressed in tanycyte processes, long processes expressing each marker separately were also seen in variable proportions between the different specimens.

While nestin and Sox2 expression was mainly restricted to the proximal border of the third ventricle, an exception was seen in the suprachiasmatic nucleus (Fig. 2a, b, Fig. 7a), which contained a population of small stellate nestin/Sox2 co-expressing cells at distance from the ventricle (Fig. 7b). The five NPC markers were detected in the suprachiasmatic nucleus (Table 3 ). Eleven $\pm 2.0 \%$ of suprachiasmatic cells co-expressed nestin and Sox2, and among this population, $74.7 \pm 10.4 \%$ expressed vimentin (Fig. 7c-e), $80.9 \pm 5.5 \%$ expressed GLAST (Fig. 7f-h) and $65.6 \pm 10.6 \%$ expressed GFAP (Fig. 7i-k), implying that at least $21 \%$ of nestin/Sox2-positive cells also express vimentin, GLAST and GFAP. Since Sox2 expression was previously reported to co-localise with neuronal markers in the rodent suprachiasmatic nucleus (Hoefflin \& Carter, 2014), we performed a triple staining for Sox2, GLAST and NeuN to evaluate whether NPC markers could be found in NeuN-expressing neurons. NeuN was only expressed in a small fraction of suprachiasmatic neurons (Fig. $7 \mathrm{~m}$ ), as already observed in rats (Geoghegan \& Carter, 2008). We found no evidence of GLAST/Sox2 co-expression in NeuN-positive neurons (Fig. 7l, m).

Proliferative cells, identified by their expression of the cell cycle marker Ki67, were detected near the third ventricle border in variable proportions in $6 / 7$ hypothalami. We identified only two nestin/Sox2-positive cells that co-expressed Ki67 in one specimen in the ribbon and at the level of a bud (Fig. 8a-e). Most Ki67-labeled cells co-expressed the microglia marker CD68 (Fig. 8f-h). 
Comparison of the stainings between the different cell populations showed that the fraction of Sox2-positive cells that co-expressed nestin was higher in the ribbon $63.2 \pm$ $3.4 \%)$ compared to ependymal $(39.3 \pm 4.1 \%)$ and suprachiasmatic cells $(37.3 \pm 4.8 \%)$ (ANOVA with Tukey post-hoc test, $\mathrm{p}<0.01$ ). However, when the population of nestin/Sox2positive cells was considered, the fraction that co-expressed vimentin, GFAP or GLAST was not different between the ribbon, the ependymal layer and the suprachiasmatic nucleus (Kruskal-Wallis One Way Analysis of Variance on Ranks with Dunn's post-hoc test, $p>0.05$ ). In buds, the population of nestin/Sox2-positive cells was enriched (ANOVA with Tukey posthoc test, $p<0.001$ ) and the fraction of nestin/Sox2-positive cells that also expressed GLAST was higher compared to the ribbon and the suprachiasmatic nucleus (Kruskal-Wallis One Way Analysis of Variance on Ranks with Dunn's post-hoc test, $p<0.05)$.

\section{The rodent and grey mouse lemur hypothalamus}

The organization of the third ventricular border significantly differed between human and rodents. The rodent third ventricle wall did not exhibit the hypocellular gap and ribbon of NPC marker co-expressing cells (Fig. 9a-k). Co-expression of nestin, Sox2 and vimentin was essentially restricted to the tanycytes with the exception of very occasional ependymal cells (Fig. 9a-k and Table 4). Noteworthy, significant differences were seen between the mouse and rat third ventricle wall. While the mouse ventricular border was composed of a regular layer of ependymal cells (Fig. 9a, e), the rat one was much more irregular with thickenings and evaginations of the ependymal layer frequently protruding in the dorsal part of the ventricle (Fig. 9i). The mouse (Fig. 10a-d) and rat (Fig. 10e-h) suprachiasmatic nucleus contained a population of Sox2-positive cells that did not co-express nestin nor vimentin.

The organization and expression profile of the grey mouse lemur third ventricle region was reminiscent of that found in mice. The third ventricle wall was composed of a regular layer of ependymal cells devoid of a gap-and-ribbon organization (Fig. 9l, o). Co-expression of Sox2 and vimentin was detected in ependymal cells (Fig. 9I-n) and tanycytes (Fig. 9o-q 
and Table 4). The suprachiasmatic nucleus contained Sox2-positive cells that did not coexpress vimentin (Fig. 10i-k).

\section{The human SVZ and the dentate gyrus of the hippocampus}

In parallel with the analysis of the human hypothalamus, we evaluated the expression of NPC markers in the two classical neurogenic niches, the SVZ and the hippocampal dentate gyrus.

The SVZ exhibited a similar pattern of NPC marker expression as the third ventricle, with a ribbon of small process-bearing cells co-expressing nestin, Sox2, vimentin, GLAST and GFAP (Fig. 11 and Table 3), separated from the ependymal layer by a hypocellular gap enriched in GLAST (Fig. 11i, k) and GFAP immunoreactivity (Fig. 11m, o). Ependymal cells expressed Sox2, GLAST, and, at varying levels, vimentin, nestin and GFAP (Fig. 11 and Table 3). This expression profile was observed at the different rostro-caudal and dorsoventral levels of the lateral ventricle analyzed. However, differences were noted compared to the third ventricle. The SVZ exhibited a more uniform organization, with a more regular ribbon and a thinner gap compared to the third ventricle (e.g. compare Fig. 11a-d to Fig. 3bd). While buds similar to those found in the third ventricle were observed (not shown), crowns and rosettes of ependymal cells were not seen. With regard to the expression of NPC markers, detection of nestin in ependymal cells was much rarer than in the third ventricle while strong vimentin immunoreactivity was more consistently observed in these cells (Fig. $11 \mathrm{e}, \mathrm{g})$.

In the hippocampus, a population of radial stem cells has been described in the SGZ of the dentate gyrus in several species including rodents and non-human primates (Aizawa, Ageyama, Terao, \& Hisatsune, 2011; Gonçalves et al., 2016). We failed to detect Sox2expressing cells in the dentate gyrus and nestin immunoreactivity was restricted to capillaries (Fig. 12a). The lack of Sox2 staining was not due to a technical detection problem since Sox2 expression was readily observable on the same sections along the border of the temporal horn of the lateral ventricle in ependymal and ribbon cells (Fig. 12a, inset). No 
GLAST immunoreactivity was observed in the dentate gyrus region (not shown). Moreover, while GFAP and vimentin were detected in small stellate cells close to the dentate gyrus, they were not seen in subgranular cells with a radial morphology (Fig. 12b, c).

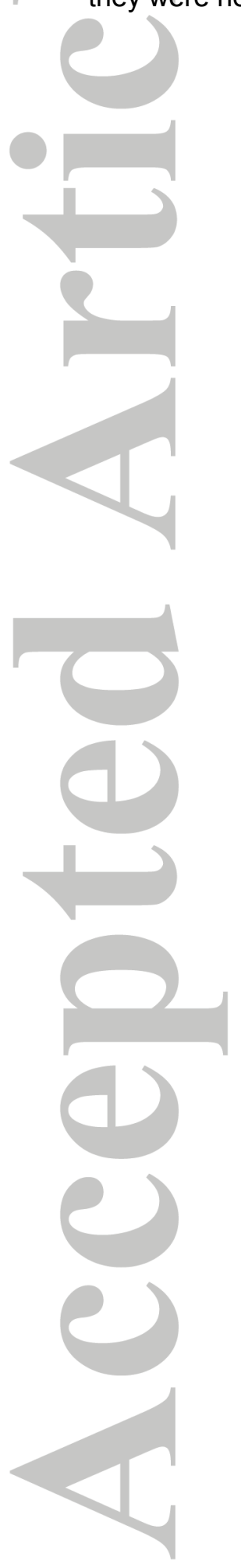




\section{Discussion}

Studies conducted in rodents have shown that the adult hypothalamus contains a neurogenic niche, with local NPCs that give birth to glial and neuronal cells in the nearby hypothalamic parenchyma (Chaker et al., 2016; Haan et al., 2013; Li et al., 2012; S. C. Robins et al., 2013; Sarah C. Robins et al., 2013). In the adult human hypothalamus, the recent identification of cells expressing the neuroblasts marker DCX, some of which exhibit a morphology characteristic of very immature neuronal progenitors (Batailler et al., 2014), raised the possibility that a local niche of NPCs may exist within this structure. Here we identify in the adult human hypothalamus four populations of cells, ependymal cells, ventricular ribbon cells, tanycytes and suprachiasmatic small stellate cells, which exhibit an antigenic profile of NPCs. In rodents and grey mouse lemur, a similar antigenic profile is essentially restricted to tanycytes.

In order to identify NPCs in the human hypothalamus, we used a series of five markers known to be expressed in these cell types during embryogenesis and adulthood (Götz, Sirko, Beckers, \& Irmler, 2015; Kriegstein \& Alvarez-Buylla, 2009; Kuhn, Eisch, Spalding, \& Peterson, 2016; Vinci et al., 2016). At present, a single marker specific for neural stem cells is not available since markers found in neural stem cells are also expressed in progenitors and/or mature cells. For instance, this is the case for GFAP, which is expressed both in neural stem cells and mature astrocytes, or nestin, which is expressed in neural stem cells, neural progenitors and endothelial cells (Kuhn et al., 2016; von Bohlen und Halbach, 2011). Higher specificity can however be obtained by using a combination rather than a single marker. In the two main neurogenic niches, the SVZ and the SGZ, neural stem cells have been shown to express a repertoire of markers including GFAP, nestin, Sox2, GLAST, vimentin, BLBP and Pax6 (Kriegstein \& Alvarez-Buylla, 2009; von Bohlen und Halbach, 2011). Therefore, we performed triple immunostainings for nestin, Sox2 and vimentin,

GLAST or GFAP and we considered that cell populations expressing all markers were the 
best candidates for being considered as neural stem or progenitor cells (Kuhn et al., 2016). Noteworthy, technical constraints preclude the concomitant detection of the five markers of interest at the same time. However, our quantitative analysis showed that at least a fraction of nestin/Sox2-positive cells also expressed vimentin, GLAST and GFAP. Interestingly, GFAP discriminates neural stem cells from neural progenitors in the two classical niches in rodents since neural stem cells express GFAP but neural progenitors lose its expression (Doetsch, 2003). In addition, a recent study in mouse suggested that among tanycytes, a subpopulation of GFAP-positive alpha tanycytes exhibited neural stem cell properties (S. C. Robins et al., 2013). Therefore, if the repertoire of markers expressed by rodent neural stem cells is conserved in humans, it may be speculated that the nestin/Sox2/vimentin/GLAST/GFAP-immunoreactive ribbon, ependymal, suprachiasmatic cells and tanycytes are neural stem cells.

The ribbon of NPC marker-immunoreactive small stellate cells lining the human third ventricle is highly reminiscent of the ribbon of astrocytes described by Sanai and colleagues along the human lateral ventricles (Sanai et al., 2004). In their study, the authors identified a band of stellate cells separated from the ependyma by a hypocellular gap. SVZ ribbon cells expressed GFAP, vimentin and some of them were immunoreactive for Ki67. Importantly, by preparing astrocyte cultures from intraoperative specimens, they showed that SVZ astrocytes were capable of generating multipotent, self-renewing neurospheres, suggesting that they were bona fide neural stem cells. In the present study, and in agreement with Sanai and colleagues, the SVZ ribbon lining the lateral ventricles was found to express GFAP, vimentin as well as the other NPC markers Sox2, nestin and GLAST. Given the similar morphology and NPC marker expression profile between SVZ ribbon cells and hypothalamic ribbon cells, it may be speculated that hypothalamic ribbon cells exhibit neural stem cell properties as their SVZ counterpart. Noteworthy, the hypothalamic ribbon appears to be a characteristic feature of the human brain since it was not observed in the rodent or grey mouse lemur hypothalamus and has not been previously reported in the literature in other species. A striking difference between the lateral and the third ventricular border was the higher degree 
of irregularity in the aspect of the third ventricular border that exhibited frequent invaginations of ependymal cells, highly variable width of the gap and thickness of the ribbon. Such heterogeneity may explain why the hypothalamic ribbon was not previously identified from small samples of the human third ventricular wall (Sanai et al., 2004). In both the lateral and the third ventricular wall, we observed occasional bulges of the wall characterized by an interruption of the ependymal layer and enrichment in NPC markers. Such protrusions are described by neuropathologists as nodular gliosis (or ependymal granulations or nodular ependymitis). Even though they have been associated with central nervous system infection or ventriculomegaly (Johnson \& Johnson, 1972; Shook et al., 2014), they are also observed in non pathological brains and occur at a similar rate in young (20-40 years) and aged brains (60 and over) (Gilmore \& Bouldin, 2002; Johnson \& Johnson, 1972). The suggested origin for these structures is a proliferation of subependymal glial cells (Gilmore \& Bouldin, 2002) as a consequence of reactive gliosis. Reactive gliosis involves several characteristic features including cellular hypertrophy, up-regulation of GFAP expression (Sofroniew, 2005) and can be accompanied by the re-expression of NPC markers such as nestin and vimentin (Goc, Liu, Sisodiya, \& Thom, 2014; Götz et al., 2015). While the ventricular protrusions were highly enriched in NPC marker-expressing cells, these cells did not exhibit signs of hypertrophy and the expression of GFAP in protrusions was as intense as in the nearby hypocellular gap lying behind an intact ependyma. Moreover, NPC marker-expressing cells found in protrusions appear to be in continuity with adjacent ribbon cells. Therefore, our observations raise the possibility that protrusions may originate from the local proliferation of ribbon cells rather than reactive astrocytes. Along the same line, ventricular protrusions are not observed in mice (Shook et al., 2014), which lack a ventricular ribbon.

Co-expression of NPC markers was also detected in a substantial fraction of human third ventricle ependymal cells. Whether ependymal cells have neural stem cell properties has been a matter of debate since almost two decades but recent rodent studies suggest that they do not (discussed in (Pastrana, Silva-Vargas, \& Doetsch, 2011). Accordingly, and in agreement with in situ expression profile data (Allen brain atlas), rodent third ventricle 
ependymal cells showed ubiquitous and robust Sox2 and vimentin immunoreactivity, while most of them exhibited low to undetectable levels of nestin. Notably, studies using different expression profiling strategies and/or different antibodies (Chaker et al., 2016; Chen, Wu, Jiang, \& Zhang, 2017; Lin et al., 2015; Mirzadeh et al., 2017; S. C. Robins et al., 2013) have reported variable results as to the presence of nestin in ependymal cells of the rodent third ventricle. Whether these apparently discrepant results reflect the existence of several alternative splicing-derived isoforms and/or post-translational modifications, some of them being more specific to stem cells, remains to be determined. Another population of NPC marker co-expressing cells seen in the human hypothalamus but not in the other species was found in the suprachiasmatic nucleus. In mammals, the suprachiasmatic nucleus is the endogenous masterclock that coordinates endogenous rhythms with the external light-dark cycle thereby controlling circadian physiology and behaviour. We also found a rich population of Sox2-expressing cells in the mouse, rat and grey mouse lemur suprachiasmatic nucleus. However, these cells did not co-express nestin and/or vimentin, suggesting that they are not NPCs. Accordingly, a previous study showed that Sox2-positive cells in the rodent suprachiasmatic nucleus mostly co-expressed neuronal markers (Hoefflin \& Carter, 2014). In the human suprachiasmatic nucleus, we did not find evidence for the expression of GLAST and Sox2 in NeuN-positive mature neurons. It must be noted that NeuN immunostaining is weak and only reveals a small fraction of suprachiasmatic nucleus neurons, as previously shown in the rat (Geoghegan \& Carter, 2008), calling for caution in the interpretation of data. However, the morphological characteristics of NPC-marker expressing cells, ie, small stellate, argue in favour of a non-neuronal identity. Altogether, the observation of cells with the same NPC antigenic profile as ribbon cells in the human ependymal layer and suprachiasmatic nucleus raises the intriguing possibility that these regions may contain neural stem cells.

Tanycytes are highly specialized ependymoglial cells that line the floor and the basolateral walls of the third ventricle in the tuberal region of the hypothalamus. Tanycytes have recently emerged as hypothalamic neural stem cells (Goodman \& Hajihosseini, 2015). In 
agreement with previous studies (Bennett et al., 2009; Haan et al., 2013; Lee et al., 2012; Pérez-Martín et al., 2010; S. C. Robins et al., 2013), we here confirm that rodent tanycytes express NPC markers and expand these results to the grey mouse lemur concerning the two markers analysed, Sox 2 and vimentin. In contrast to the ventricular ribbon that is only seen in humans, our study and others show that mice, rats, sheep (Batailler et al., 2014), grey mouse lemur and humans (Baroncini et al., 2007; Koopman et al., 2017; Sidibe et al., 2010) share NPC marker-expressing tanycytes. In adult mice, lineage-tracing studies have shown that tanycytes give birth to neurons that populate nearby hypothalamic regions including the arcuate and ventromedial nuclei (Chaker et al., 2016; Haan et al., 2013; S. C. Robins et al., 2013). Interestingly, DCX-expressing cells are detected in the arcuate and ventromedial nuclei of the sheep and human hypothalamus (Batailler et al., 2014), raising the possibility that tanycytes may also be neurogenic in these species.

At present, the organization of the rodent hypothalamic stem cell niche remains vague. While we find in the human hypothalamus a gap-and-ribbon organization reminiscent of that found in the human SVZ (Sanai et al., 2004), the situation is different in rodents in which the architecture of the SVZ stem cell niche is not recapitulated in the hypothalamus (Mirzadeh, Merkle, Soriano-Navarro, Garcia-Verdugo, \& Alvarez-Buylla, 2008). Lineage-tracing studies performed in adult mice have shown that new hypothalamic neurons can be produced not only from tanycytes but also from parenchymal cells that express Sox2 and/or NG2 (Li et al., 2012; Sarah C. Robins et al., 2013). Whether tanycytes and parenchymal neurogenic cells correspond to distinct NPC populations or whether they are linked by lineage relationship is currently unknown. However, if the combination of markers expressed in the adult rodent SVZ and SGZ (Semerci \& Maletic-Savatic, 2016) is shared by the hypothalamic niche, our observation of NPC marker co-expression in tanycytes but not in parenchymal cells suggests that tanycytes are neural stem cells while parenchymal cells are more committed progenitors.

Neuroanatomical (Eriksson et al., 1998; Knoth et al., 2010) and, more recently, ${ }^{14} \mathrm{C}$ dating studies (Spalding et al., 2013), have brought evidence that a neurogenic niche exists 
in the human hippocampus. Here, we failed to detect a population of NPC marker-expressing cells in the dentate gyrus of the human hippocampus. In an extensive immunofluorescent study of neurogenesis-associated markers in the human hippocampus, Knoth and colleagues (2010) did not find radial cells, the putative neural stem cells in the rodent hippocampus (von Bohlen und Halbach, 2011) but detected Sox2/DCX and nestin/DCX coexpressing cells, i.e. early neuronal precursors, in humans up to 79 and 100 years of age, respectively. However, the expression of these markers declined with age. Since our study was conducted on samples from aged brains ( $\geq 77$ year-old), we cannot rule out the possibility that we missed these cells if present in very low number.

In the present study, our criteria for identifying NPCs were based on their molecular signature. However, proving that these cells are bona fide neural stem cells will require functional arguments, which is challenging in human studies. Neural stem cells are defined by two canonical properties, the ability to extensively self-renew and to differentiate into all three neural lineages, i.e. neuronal, astroglial and oligodendroglial. Even if it has some limitations, the neurosphere assay is commonly used to probe in vitro whether a tissue contains cells with neural stem cell properties (Pastrana et al., 2011). A study reported the possibility to grow neurospheres from rapid autopsy samples of SVZ from elderly human subjects (Leonard et al., 2009). A key to success certainly resides in the short post-mortem interval (less than 5 hours in the study by (Leonard et al., 2009) and may explain our inability to grow neurospheres from hypothalami with post-mortem intervals over 7 hours, the shortest post-mortem delay reached in our study (unpublished observations). Future neuroimaging developments enabling to detect and measure levels of adult neurogenesis in living human brains (Ho, Hooker, Sahay, Holt, \& Roffman, 2013) are eagerly awaited.

Comparative studies of adult neurogenesis in the two classical niches have revealed a great diversity in this process among species (Lindsey \& Tropepe, 2006). The general view that adult neurogenesis has undergone a phylogenetic reduction has recently been reevaluated to propose that this process may rather have evolved to optimize the functioning of neuronal networks that have to deal with new situations (Kempermann, 2012). Even though 
we need comparative data from many more species to start to draw a phylogenetic tree of adult hypothalamic neurogenesis, our results raise the intriguing possibility that the human brain may have expanded its hypothalamic neural stem cell niche compared to rodents and lemur primates. Whether this translates into higher functionally-relevant neurogenesis and a higher degree of plasticity and adaptability in hypothalamic circuits will be challenging future questions to address.
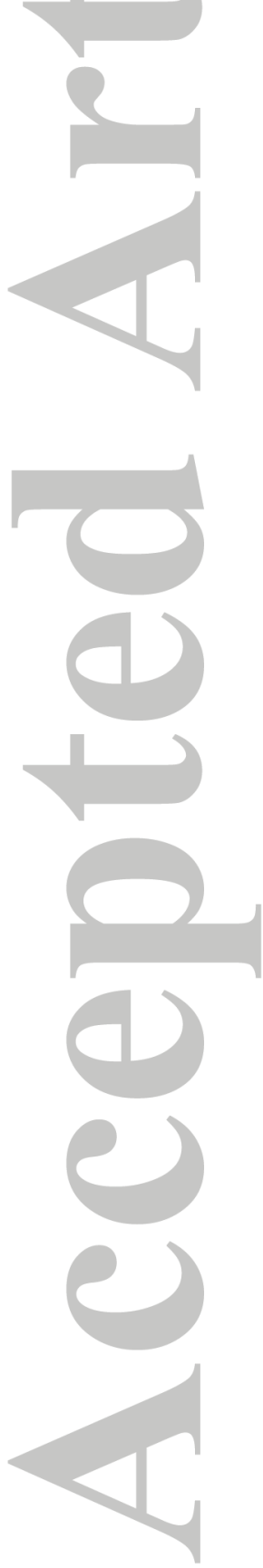


\section{References}

Adachi, K., Suemori, H., Yasuda, S.-Y., Nakatsuji, N., \& Kawase, E. (2010). Role of SOX2 in maintaining pluripotency of human embryonic stem cells. Genes to Cells: Devoted to Molecular \& Cellular Mechanisms, 15(5), 455-470. https://doi.org/10.1111/j.13652443.2010.01400.x

Aizawa, K., Ageyama, N., Terao, K., \& Hisatsune, T. (2011). Primate-specific alterations in neural stem/progenitor cells in the aged hippocampus. Neurobiology of Aging, 32(1), 140-150. https://doi.org/10.1016/j.neurobiolaging.2008.12.011

Alliot, F., Rutin, J., Leenen, P. J., \& Pessac, B. (1999). Pericytes and periendothelial cells of brain parenchyma vessels co-express aminopeptidase $\mathrm{N}$, aminopeptidase $\mathrm{A}$, and nestin. Journal of Neuroscience Research, 58(3), 367-378.

Alvarez-Buylla, A., \& Lim, D. A. (2004). For the long run: maintaining germinal niches in the adult brain. Neuron, 41(5), 683-686.

Baroncini, M., Allet, C., Leroy, D., Beauvillain, J.-C., Francke, J.-P., \& Prevot, V. (2007). Morphological evidence for direct interaction between gonadotrophin-releasing hormone neurones and astroglial cells in the human hypothalamus. Journal of Neuroendocrinology, 19(9), 691-702. https://doi.org/10.1111/j.13652826.2007.01576.x

Batailler, M., Droguerre, M., Baroncini, M., Fontaine, C., Prevot, V., \& Migaud, M. (2014). DCX-expressing cells in the vicinity of the hypothalamic neurogenic niche: a comparative study between mouse, sheep, and human tissues. The Journal of Comparative Neurology, 522(8), 1966-1985. https://doi.org/10.1002/cne.23514

Bayatti, N., Moss, J. A., Sun, L., Ambrose, P., Ward, J. F. H., Lindsay, S., \& Clowry, G. J. (2008). A molecular neuroanatomical study of the developing human neocortex from 8 to 17 postconceptional weeks revealing the early differentiation of the subplate and subventricular zone. Cerebral Cortex (New York, N.Y.: 1991), 18(7), 1536-1548. https://doi.org/10.1093/cercor/bhm184 
Béguin, P. C., Gosselin, H., Mamarbachi, M., \& Calderone, A. (2012). Nestin expression is lost in ventricular fibroblasts during postnatal development of the rat heart and reexpressed in scar myofibroblasts. Journal of Cellular Physiology, 227(2), 813-820. https://doi.org/10.1002/jcp.22794

Bennett, L., Yang, M., Enikolopov, G., \& lacovitti, L. (2009). Circumventricular organs: a novel site of neural stem cells in the adult brain. Molecular and Cellular Neurosciences, 41(3), 337-347. https://doi.org/10.1016/j.mcn.2009.04.007

Bergmann, O., Liebl, J., Bernard, S., Alkass, K., Yeung, M. S. Y., Steier, P., ... Frisén, J. (2012). The age of olfactory bulb neurons in humans. Neuron, 74(4), 634-639. https://doi.org/10.1016/j.neuron.2012.03.030

Bergmann, O., Spalding, K. L., \& Frisén, J. (2015). Adult Neurogenesis in Humans. Cold Spring Harbor Perspectives in Biology, 7(7), a018994. https://doi.org/10.1101/cshperspect.a018994

Bons, N., Silhol, S., Barbié, V., Mestre-Francés, N., \& Albe-Fessard, D. (1998). A stereotaxic atlas of the grey lesser mouse lemur brain (Microcebus murinus). Brain Research Bulletin, 46(1-2), 1-173.

Chaker, Z., George, C., Petrovska, M., Caron, J.-B., Lacube, P., Caillé, I., \& Holzenberger, M. (2016). Hypothalamic neurogenesis persists in the aging brain and is controlled by energy-sensing IGF-I pathway. Neurobiology of Aging, 41, 64-72. https://doi.org/10.1016/j.neurobiolaging.2016.02.008

Chen, R., Wu, X., Jiang, L., \& Zhang, Y. (2017). Single-Cell RNA-Seq Reveals Hypothalamic Cell Diversity. Cell Reports, 18(13), 3227-3241. https://doi.org/10.1016/j.celrep.2017.03.004

Chierico, L., Rizzello, L., Guan, L., Joseph, A. S., Lewis, A., \& Battaglia, G. (2017). The role of the two splice variants and extranuclear pathway on Ki-67 regulation in non-cancer and cancer cells. PloS One, 12(2), e0171815. https://doi.org/10.1371/journal.pone.0171815 
Ciechomska, I. A., Przanowski, P., Jackl, J., Wojtas, B., \& Kaminska, B. (2016). BIX01294, an inhibitor of histone methyltransferase, induces autophagy-dependent differentiation of glioma stem-like cells. Scientific Reports, 6, 38723. https://doi.org/10.1038/srep38723

Dahiya, S., Lee, D. Y., \& Gutmann, D. H. (2011). Comparative characterization of the human and mouse third ventricle germinal zones. Journal of Neuropathology and $\begin{array}{lll}\text { Experimental Neurology, } & \text { 60(7), }\end{array}$ https://doi.org/10.1097/NEN.0b013e31822200aa

Ding, D., Xu, H., Liang, Q., Xu, L., Zhao, Y., \& Wang, Y. (2012). Over-expression of Sox2 in C3H10T1/2 cells inhibits osteoblast differentiation through Wnt and MAPK signalling pathways. International Orthopaedics, 36(5), 1087-1094. https://doi.org/10.1007/s00264-011-1368-6

Djogo, T., Robins, S. C., Schneider, S., Kryzskaya, D., Liu, X., Mingay, A., ... Kokoeva, M. V. (2016). Adult NG2-Glia Are Required for Median Eminence-Mediated Leptin Sensing and Body Weight Control. Cell Metabolism, 23(5), 797-810. https://doi.org/10.1016/j.cmet.2016.04.013

Doetsch, F. (2003). The glial identity of neural stem cells. Nature Neuroscience, 6(11), 11271134. https://doi.org/10.1038/nn1144

Duhem-Tonnelle, V., Bièche, I., Vacher, S., Loyens, A., Maurage, C.-A., Collier, F., ... Sharif, A. (2010). Differential distribution of erbB receptors in human glioblastoma multiforme: expression of erbB3 in CD133-positive putative cancer stem cells. Journal of Neuropathology and Experimental Neurology, 69(6), 606-622. https://doi.org/10.1097/NEN.0b013e3181e00579

Engel, T., Schindler, C. K., Sanz-Rodriguez, A., Conroy, R. M., Meller, R., Simon, R. P., \& Henshall, D. C. (2011). Expression of neurogenesis genes in human temporal lobe epilepsy with hippocampal sclerosis. International Journal of Physiology, Pathophysiology and Pharmacology, 3(1), 38-47. 
Eriksson, P. S., Perfilieva, E., Björk-Eriksson, T., Alborn, A. M., Nordborg, C., Peterson, D. A., \& Gage, F. H. (1998). Neurogenesis in the adult human hippocampus. Nature Medicine, 4(11), 1313-1317. https://doi.org/10.1038/3305

Ernst, A., Alkass, K., Bernard, S., Salehpour, M., Perl, S., Tisdale, J., ... Frisén, J. (2014). Neurogenesis in the striatum of the adult human brain. Cell, 156(5), 1072-1083. https://doi.org/10.1016/j.cell.2014.01.044

Geoghegan, D., \& Carter, D. A. (2008). A novel site of adult doublecortin expression: neuropeptide neurons within the suprachiasmatic nucleus circadian clock. BMC Neuroscience, 9, 2. https://doi.org/10.1186/1471-2202-9-2

Gilmore, J. H., \& Bouldin, T. W. (2002). Analysis of ependymal abnormalities in subjects with schizophrenia, bipolar disorder, and depression. Schizophrenia Research, 57(2-3), 267-271.

Goc, J., Liu, J. Y. W., Sisodiya, S. M., \& Thom, M. (2014). A spatiotemporal study of gliosis in relation to depth electrode tracks in drug-resistant epilepsy. The European Journal of Neuroscience, 39(12), 2151-2162. https://doi.org/10.1111/ejn.12548

Gonçalves, J. T., Schafer, S. T., \& Gage, F. H. (2016). Adult Neurogenesis in the Hippocampus: From Stem Cells to Behavior. Cell, 167(4), 897-914. https://doi.org/10.1016/j.cell.2016.10.021

Goodman, T., \& Hajihosseini, M. K. (2015). Hypothalamic tanycytes-masters and servants of metabolic, neuroendocrine, and neurogenic functions. Frontiers in Neuroscience, 9, 387. https://doi.org/10.3389/fnins.2015.00387

Götz, M., Sirko, S., Beckers, J., \& Irmler, M. (2015). Reactive astrocytes as neural stem or progenitor cells: In vivo lineage, In vitro potential, and Genome-wide expression analysis. Glia, 63(8), 1452-1468. https://doi.org/10.1002/glia.22850

Gouazé, A., Brenachot, X., Rigault, C., Krezymon, A., Rauch, C., Nédélec, E., ... Benani, A. (2013). Cerebral cell renewal in adult mice controls the onset of obesity. PloS One, 8(8), e72029. https://doi.org/10.1371/journal.pone.0072029 
Guichet, P.-O., Bieche, I., Teigell, M., Serguera, C., Rothhut, B., Rigau, V., ... Hugnot, J.-P. (2013). Cell death and neuronal differentiation of glioblastoma stem-like cells induced by neurogenic transcription factors. Glia, 61(2), 225-239. https://doi.org/10.1002/glia.22429

Haan, N., Goodman, T., Najdi-Samiei, A., Stratford, C. M., Rice, R., El Agha, E., ... Hajihosseini, M. K. (2013). Fgf10-expressing tanycytes add new neurons to the appetite/energy-balance regulating centers of the postnatal and adult hypothalamus. The Journal of Neuroscience: The Official Journal of the Society for Neuroscience, 33(14), 6170-6180. https://doi.org/10.1523/JNEUROSCI.2437-12.2013

Harkin, L. F., Gerrelli, D., Gold Diaz, D. C., Santos, C., Alzu'bi, A., Austin, C. A., \& Clowry, G. J. (2016). Distinct expression patterns for type II topoisomerases IIA and IIB in the early foetal human telencephalon. Journal of Anatomy, 228(3), 452-463. https://doi.org/10.1111/joa.12416

Helfer, G., Ross, A. W., Thomson, L. M., Mayer, C. D., Stoney, P. N., McCaffery, P. J., \& Morgan, P. J. (2016). A neuroendocrine role for chemerin in hypothalamic remodelling and photoperiodic control of energy balance. Scientific Reports, 6, 26830. https://doi.org/10.1038/srep26830

Ho, N. F., Hooker, J. M., Sahay, A., Holt, D. J., \& Roffman, J. L. (2013). In vivo imaging of adult human hippocampal neurogenesis: progress, pitfalls and promise. Molecular Psychiatry, 18(4), 404-416. https://doi.org/10.1038/mp.2013.8

Hoefflin, S., \& Carter, D. A. (2014). Neuronal expression of SOX2 is enriched in specific hypothalamic cell groups. Journal of Chemical Neuroanatomy, 61-62, 153-160. https://doi.org/10.1016/j.jchemneu.2014.09.003

Hofman, M. A., Zhou, J. N., \& Swaab, D. F. (1996). Suprachiasmatic nucleus of the human brain: an immunocytochemical and morphometric analysis. The Anatomical Record, 244(4), 552-562. https://doi.org/10.1002/(SICI)1097-0185(199604)244:4<552::AIDAR13>3.0.CO;2-O 
Howard, B., Chen, Y., \& Zecevic, N. (2006). Cortical progenitor cells in the developing human telencephalon. Glia, 53(1), 57-66. https://doi.org/10.1002/glia.20259

Huang, L., DeVries, G. J., \& Bittman, E. L. (1998). Photoperiod regulates neuronal bromodeoxyuridine labeling in the brain of a seasonally breeding mammal. Journal of Neurobiology, 36(3), 410-420.

Johnson, K. P., \& Johnson, R. T. (1972). Granular ependymitis. Occurrence in myxovirus infected rodents and prevalence in man. The American Journal of Pathology, 67(3), $511-526$.

Jourdon, A., Gresset, A., Spassky, N., Charnay, P., Topilko, P., \& Santos, R. (2015). Prss56, a novel marker of adult neurogenesis in the mouse brain. Brain Structure \& Function. https://doi.org/10.1007/s00429-015-1171-z

Kempermann, G. (2012). New neurons for "survival of the fittest." Nature Reviews. Neuroscience, 13(10), 727-736. https://doi.org/10.1038/nrn3319

Knoth, R., Singec, I., Ditter, M., Pantazis, G., Capetian, P., Meyer, R. P., ... Kempermann, G. (2010). Murine features of neurogenesis in the human hippocampus across the lifespan from 0 to 100 years. PloS One, 5(1), e8809. https://doi.org/10.1371/journal.pone.0008809

Kokoeva, M. V., Yin, H., \& Flier, J. S. (2005). Neurogenesis in the hypothalamus of adult mice: potential role in energy balance. Science (New York, N.Y.), 310(5748), 679683. https://doi.org/10.1126/science. 1115360

Kokoeva, M. V., Yin, H., \& Flier, J. S. (2007). Evidence for constitutive neural cell proliferation in the adult murine hypothalamus. The Journal of Comparative Neurology, 505(2), 209-220. https://doi.org/10.1002/cne.21492

Koopman, A. C. M., Taziaux, M., \& Bakker, J. (2017). Age-Related Changes in the Morphology of Tanycytes in the Human Female Infundibular Nucleus/Median Eminence. Journal of Neuroendocrinology. https://doi.org/10.1111/jne.12467 
Kriegstein, A., \& Alvarez-Buylla, A. (2009). The glial nature of embryonic and adult neural stem cells. Annual Review of Neuroscience, 32, 149-184. https://doi.org/10.1146/annurev.neuro.051508.135600

Kuhn, H. G., Eisch, A. J., Spalding, K., \& Peterson, D. A. (2016). Detection and Phenotypic Characterization of Adult Neurogenesis. Cold Spring Harbor Perspectives in Biology, 8(3), a025981. https://doi.org/10.1101/cshperspect.a025981

Langlet, F., Mullier, A., Bouret, S. G., Prevot, V., \& Dehouck, B. (2013). Tanycyte-like cells form a blood-cerebrospinal fluid barrier in the circumventricular organs of the mouse brain. The Journal of Comparative Neurology, 521(15), 3389-3405. https://doi.org/10.1002/cne.23355

Lee, D. A., Bedont, J. L., Pak, T., Wang, H., Song, J., Miranda-Angulo, A., ... Blackshaw, S. (2012). Tanycytes of the hypothalamic median eminence form a diet-responsive neurogenic niche. Nature Neuroscience, 15(5), 700-702. https://doi.org/10.1038/nn.3079

Lee, D. A., Yoo, S., Pak, T., Salvatierra, J., Velarde, E., Aja, S., \& Blackshaw, S. (2014). Dietary and sex-specific factors regulate hypothalamic neurogenesis in young adult mice. Frontiers in Neuroscience, 8, 157. https://doi.org/10.3389/fnins.2014.00157

Leonard, B. W., Mastroeni, D., Grover, A., Liu, Q., Yang, K., Gao, M., ... Rogers, J. (2009). Subventricular zone neural progenitors from rapid brain autopsies of elderly subjects with and without neurodegenerative disease. The Journal of Comparative Neurology, 515(3), 269-294. https://doi.org/10.1002/cne.22040

Li, J., Tang, Y., \& Cai, D. (2012). IKKß/NF-KB disrupts adult hypothalamic neural stem cells to mediate a neurodegenerative mechanism of dietary obesity and pre-diabetes. Nature Cell Biology, 14(10), 999-1012. https://doi.org/10.1038/ncb2562

Li, J., Tang, Y., Purkayastha, S., Yan, J., \& Cai, D. (2014). Control of obesity and glucose intolerance via building neural stem cells in the hypothalamus. Molecular Metabolism, 3(3), 313-324. https://doi.org/10.1016/j.molmet.2014.01.012 
Lin, R., Cai, J., Nathan, C., Wei, X., Schleidt, S., Rosenwasser, R., \& lacovitti, L. (2015). Neurogenesis is enhanced by stroke in multiple new stem cell niches along the ventricular system at sites of high BBB permeability. Neurobiology of Disease, 74, 229-239. https://doi.org/10.1016/j.nbd.2014.11.016

Lindsey, B. W., \& Tropepe, V. (2006). A comparative framework for understanding the biological principles of adult neurogenesis. Progress in Neurobiology, 80(6), 281-307. https://doi.org/10.1016/j.pneurobio.2006.11.007

Lledo, P.-M., \& Valley, M. (2016). Adult Olfactory Bulb Neurogenesis. Cold Spring Harbor Perspectives in Biology, 8(8). https://doi.org/10.1101/cshperspect.a018945

Louis, D. N., Ohgaki, H., Wiestler, O. D., Cavenee, W. K., Burger, P. C., Jouvet, A., ... Kleihues, P. (2007). The 2007 WHO classification of tumours of the central nervous system. Acta Neuropathologica, 114(2), 97-109. https://doi.org/10.1007/s00401-007$0243-4$

Ludwig, K., \& Kornblum, H. I. (2017). Molecular markers in glioma. Journal of NeuroOncology. https://doi.org/10.1007/s11060-017-2379-y

Mai, J. K., Paxinos, G., \& Voss, T. (2008). Atlas of the human brain, 3rd Edition (Academic press). San Diego.

McNay, D. E. G., Briançon, N., Kokoeva, M. V., Maratos-Flier, E., \& Flier, J. S. (2012). Remodeling of the arcuate nucleus energy-balance circuit is inhibited in obese mice. The Journal of Clinical Investigation, 122(1), 142-152. https://doi.org/10.1172/JCl43134

Mezaki, Y., Morii, M., Hebiguchi, T., Yoshikawa, K., Yamaguchi, N., Miura, M., ... Senoo, H. (2013). Differential increases in the expression of intermediate filament proteins and concomitant morphological changes of transdifferentiating rat hepatic stellate cells observed in vitro. Acta Histochemica Et Cytochemica, 46(5), 137-143. https://doi.org/10.1267/ahc. 13007

Migaud, M., Batailler, M., Segura, S., Duittoz, A., Franceschini, I., \& Pillon, D. (2010). Emerging new sites for adult neurogenesis in the mammalian brain: a comparative 
study between the hypothalamus and the classical neurogenic zones. The European Journal of Neuroscience, 32(12), 2042-2052. https://doi.org/10.1111/j.14609568.2010.07521.x

Ming, G., \& Song, H. (2005). Adult neurogenesis in the mammalian central nervous system. Annual Review of Neuroscience, 28, 223-250. https://doi.org/10.1146/annurev.neuro.28.051804.101459

Mirzadeh, Z., Kusne, Y., Duran-Moreno, M., Cabrales, E., Gil-Perotin, S., Ortiz, C., ... Alvarez-Buylla, A. (2017). Bi- and uniciliated ependymal cells define continuous floorplate-derived tanycytic territories. Nature Communications, 8, 13759. https://doi.org/10.1038/ncomms13759

Mirzadeh, Z., Merkle, F. T., Soriano-Navarro, M., Garcia-Verdugo, J. M., \& Alvarez-Buylla, A. (2008). Neural stem cells confer unique pinwheel architecture to the ventricular surface in neurogenic regions of the adult brain. Cell Stem Cell, 3(3), 265-278. https://doi.org/10.1016/j.stem.2008.07.004

Monier, A., Evrard, P., Gressens, P., \& Verney, C. (2006). Distribution and differentiation of microglia in the human encephalon during the first two trimesters of gestation. The Journal of Comparative Neurology, 499(4), 565-582. https://doi.org/10.1002/cne.21123

Mullier, A., Bouret, S. G., Prevot, V., \& Dehouck, B. (2010). Differential distribution of tight junction proteins suggests a role for tanycytes in blood-hypothalamus barrier regulation in the adult mouse brain. The Journal of Comparative Neurology, 518(7), 943-962. https://doi.org/10.1002/cne.22273

Narita, K., Matsuda, Y., Seike, M., Naito, Z., Gemma, A., \& Ishiwata, T. (2014). Nestin regulates proliferation, migration, invasion and stemness of lung adenocarcinoma. International Journal of Oncology, 44(4), 1118-1130. https://doi.org/10.3892/ijo.2014.2278

Nogueira, A. B., Sogayar, M. C., Colquhoun, A., Siqueira, S. A., Nogueira, A. B., Marchiori, P. E., \& Teixeira, M. J. (2014). Existence of a potential neurogenic system in the adult 
human brain. Journal of Translational Medicine, 12, 75. https://doi.org/10.1186/1479$5876-12-75$

Noorian, A. R., Taylor, G. M., Annerino, D. M., \& Greene, J. G. (2011). Neurochemical phenotypes of myenteric neurons in the rhesus monkey. The Journal of Comparative Neurology, 519(17), 3387-3401. https://doi.org/10.1002/cne.22679

Pastrana, E., Silva-Vargas, V., \& Doetsch, F. (2011). Eyes wide open: a critical review of sphere-formation as an assay for stem cells. Cell Stem Cell, 8(5), 486-498. https://doi.org/10.1016/j.stem.2011.04.007

Paxinos, G., \& Franklin, K. B. J. (2001). The Mouse Brain in Stereotaxic Coordinates. Second Edition. Elsevier, Academic Press.

Pencea, V., Bingaman, K. D., Wiegand, S. J., \& Luskin, M. B. (2001). Infusion of brainderived neurotrophic factor into the lateral ventricle of the adult rat leads to new neurons in the parenchyma of the striatum, septum, thalamus, and hypothalamus. The Journal of Neuroscience: The Official Journal of the Society for Neuroscience, 21(17), 6706-6717.

Pérez-Martín, M., Cifuentes, M., Grondona, J. M., López-Avalos, M. D., Gómez-Pinedo, U., García-Verdugo, J. M., \& Fernández-Llebrez, P. (2010). IGF-I stimulates neurogenesis in the hypothalamus of adult rats. The European Journal of Neuroscience, 31(9), 1533-1548. https://doi.org/10.1111/j.1460-9568.2010.07220.x

Pierce, A. A., \& Xu, A. W. (2010). De novo neurogenesis in adult hypothalamus as a compensatory mechanism to regulate energy balance. The Journal of Neuroscience: The Official Journal of the Society for Neuroscience, 30(2), 723-730. https://doi.org/10.1523/JNEUROSCI.2479-09.2010

Poché, R. A., Furuta, Y., Chaboissier, M.-C., Schedl, A., \& Behringer, R. R. (2008). Sox9 is expressed in mouse multipotent retinal progenitor cells and functions in Müller glial cell development. The Journal of Comparative Neurology, 510(3), 237-250. https://doi.org/10.1002/cne.21746 
Pulford, K. A., Rigney, E. M., Micklem, K. J., Jones, M., Stross, W. P., Gatter, K. C., \& Mason, D. Y. (1989). KP1: a new monoclonal antibody that detects a monocyte/macrophage associated antigen in routinely processed tissue sections. Journal of Clinical Pathology, 42(4), 414-421.

Quiñones-Hinojosa, A., Sanai, N., Soriano-Navarro, M., Gonzalez-Perez, O., Mirzadeh, Z., Gil-Perotin, S., ... Alvarez-Buylla, A. (2006). Cellular composition and cytoarchitecture of the adult human subventricular zone: a niche of neural stem cells. The Journal of Comparative Neurology, 494(3), 415-434. https://doi.org/10.1002/cne.20798

Roberts, R. C., Roche, J. K., \& McCullumsmith, R. E. (2014). Localization of excitatory amino acid transporters EAAT1 and EAAT2 in human postmortem cortex: a light and electron microscopic study. Neuroscience, 277, 522-540. https://doi.org/10.1016/j.neuroscience.2014.07.019

Robins, S. C., Stewart, I., McNay, D. E., Taylor, V., Giachino, C., Goetz, M., ... Placzek, M. (2013). a-Tanycytes of the adult hypothalamic third ventricle include distinct populations of FGF-responsive neural progenitors. Nature Communications, 4, 2049. https://doi.org/10.1038/ncomms3049

Robins, Sarah C., Trudel, E., Rotondi, O., Liu, X., Djogo, T., Kryzskaya, D., ... Kokoeva, M. V. (2013). Evidence for NG2-glia derived, adult-born functional neurons in the $\begin{array}{llll}\text { hypothalamus. } & \text { One, } & \text { e78236. }\end{array}$ https://doi.org/10.1371/journal.pone.0078236

Rojczyk-Gołębiewska, E., Pałasz, A., \& Wiaderkiewicz, R. (2014). Hypothalamic subependymal niche: a novel site of the adult neurogenesis. Cellular and Molecular Neurobiology, 34(5), 631-642. https://doi.org/10.1007/s10571-014-0058-5

Romijn, H. J., van Uum, J. F., Breedijk, I., Emmering, J., Radu, I., \& Pool, C. W. (1999). Double immunolabeling of neuropeptides in the human hypothalamus as analyzed by confocal laser scanning fluorescence microscopy. The Journal of Histochemistry and Cytochemistry: Official Journal of the Histochemistry Society, 47(2), 229-236. 
Saentaweesuk, W., Araki, N., Vaeteewoottacharn, K., Silsirivanit, A., Seubwai, W., Talabnin, C., ... Wongkham, C. (2017). Activation of Vimentin is Critical to Promote a Metastatic Potential of Cholangiocarcinoma Cells. Oncology Research. https://doi.org/10.3727/096504017X15009778205068

Sanai, N., Tramontin, A. D., Quiñones-Hinojosa, A., Barbaro, N. M., Gupta, N., Kunwar, S., Alvarez-Buylla, A. (2004). Unique astrocyte ribbon in adult human brain contains neural stem cells but lacks chain migration. Nature, 427(6976), 740-744. https://doi.org/10.1038/nature02301

Semerci, F., \& Maletic-Savatic, M. (2016). Transgenic mouse models for studying adult neurogenesis. Frontiers in Biology, 11(3), 151-167. https://doi.org/10.1007/s11515016-1405-3

Sharif, A., Ojeda, S. R., \& Prevot, V. (2014). Neurogenesis and Gliogenesis in the Postnatal Hypothalamus: A New Level of Plasticity for the Regulation of Hypothalamic Function? (M. P. Junier \& S. G. Kernie, Eds.). Totowa: Humana Press Inc.

Shigemoto-Mogami, Y., Hoshikawa, K., Goldman, J. E., Sekino, Y., \& Sato, K. (2014). Microglia enhance neurogenesis and oligodendrogenesis in the early postnatal subventricular zone. The Journal of Neuroscience: The Official Journal of the Society for Neuroscience, 34(6), 2231-2243. https://doi.org/10.1523/JNEUROSCI.161913.2014

Shook, B. A., Lennington, J. B., Acabchuk, R. L., Halling, M., Sun, Y., Peters, J., ... Conover, J. C. (2014). Ventriculomegaly associated with ependymal gliosis and declines in barrier integrity in the aging human and mouse brain. Aging Cell, 13(2), 340-350. https://doi.org/10.1111/acel.12184

Sidibe, A., Mullier, A., Chen, P., Baroncini, M., Boutin, J. A., Delagrange, P., ... Jockers, R. (2010). Expression of the orphan GPR50 protein in rodent and human dorsomedial hypothalamus, tanycytes and median eminence. Journal of Pineal Research, 48(3), 263-269. https://doi.org/10.1111/j.1600-079X.2010.00750.x 
Sofroniew, M. V. (2005). Reactive astrocytes in neural repair and protection. The Neuroscientist: A Review Journal Bringing Neurobiology, Neurology and Psychiatry, 11(5), 400-407. https://doi.org/10.1177/1073858405278321

Spalding, K. L., Bergmann, O., Alkass, K., Bernard, S., Salehpour, M., Huttner, H. B., ... Frisén, J. (2013). Dynamics of hippocampal neurogenesis in adult humans. Cell, 153(6), 1219-1227. https://doi.org/10.1016/j.cell.2013.05.002

Sun, X., Bizhanova, A., Matheson, T. D., Yu, J., Zhu, L. J., \& Kaufman, P. D. (2017). Ki-67 Contributes to Normal Cell Cycle Progression and Inactive $X$ Heterochromatin in p21 Checkpoint-Proficient Human Cells. Molecular and Cellular Biology, 37(17). https://doi.org/10.1128/MCB.00569-16

Swanson, L. W. (2004). Brain Maps: Structure of the Rat Brain. Third Edition. Elsevier, Academic Press.

Takamori, Y., Mori, T., Wakabayashi, T., Nagasaka, Y., Matsuzaki, T., \& Yamada, H. (2009). Nestin-positive microglia in adult rat cerebral cortex. Brain Research, 1270, 10-18. https://doi.org/10.1016/j.brainres.2009.03.014

Talele, N. P., Fradette, J., Davies, J. E., Kapus, A., \& Hinz, B. (2015). Expression of aSmooth Muscle Actin Determines the Fate of Mesenchymal Stromal Cells. Stem Cell Reports, 4(6), 1016-1030. https://doi.org/10.1016/j.stemcr.2015.05.004

Tardito, S., Oudin, A., Ahmed, S. U., Fack, F., Keunen, O., Zheng, L., ... Gottlieb, E. (2015). Glutamine synthetase activity fuels nucleotide biosynthesis and supports growth of glutamine-restricted glioblastoma. Nature Cell Biology, 17(12), 1556-1568. https://doi.org/10.1038/ncb3272

van Wamelen, D. J., Aziz, N. A., Anink, J. J., van Steenhoven, R., Angeloni, D., Fraschini, F., ... Swaab, D. F. (2013). Suprachiasmatic nucleus neuropeptide expression in patients with Huntington's Disease. Sleep, 36(1), 117-125. https://doi.org/10.5665/sleep.2314

Vinci, L., Ravarino, A., Fanos, V., Naccarato, A. G., Senes, G., Gerosa, C., ... Ambu, R. (2016). Immunohistochemical markers of neural progenitor cells in the early 
embryonic human cerebral cortex. European Journal of Histochemistry: EJH, 60(1), 2563. https://doi.org/10.4081/ejh.2016.2563

von Bohlen und Halbach, O. (2011). Immunohistological markers for proliferative events, gliogenesis, and neurogenesis within the adult hippocampus. Cell and Tissue Research, 345(1), 1-19. https://doi.org/10.1007/s00441-011-1196-4

Wang, J. L., Lim, A. S., Chiang, W.-Y., Hsieh, W.-H., Lo, M.-T., Schneider, J. A., ... Saper, C. B. (2015). Suprachiasmatic neuron numbers and rest-activity circadian rhythms in older humans. Annals of Neurology, 78(2), 317-322. https://doi.org/10.1002/ana.24432

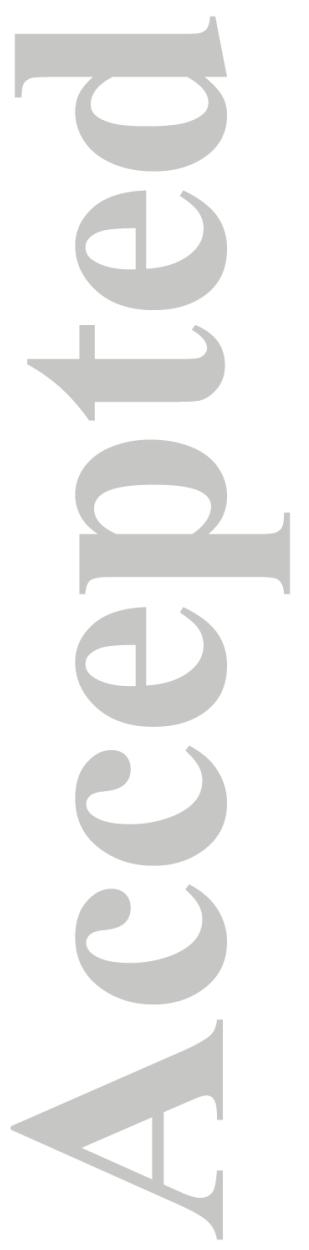


Table 1. Primary antibodies used in the study.

\begin{tabular}{|c|c|c|c|c|}
\hline Antigen & $\begin{array}{l}\text { Host \& } \\
\text { Clonality }\end{array}$ & Dilution & $\begin{array}{l}\text { Reference } \\
\text { (Company) } \\
\text { RRID number } \\
\end{array}$ & Immunogen \\
\hline Sox2 & $\begin{array}{l}\text { goat } \\
\text { polyclonal }\end{array}$ & $1 / 300$ & $\begin{array}{l}\text { sc-17320 (Santa } \\
\text { Cruz) } \\
\text { RRID:AB_2286684 }\end{array}$ & $\begin{array}{l}\text { Peptide corresponding to amino acids } 277-293 \text { of } \\
\text { human Sox2 (YLPGAEVPEPAAPSRLH), affinity- } \\
\text { purified serum (Poché, Furuta, Chaboissier, Schedl, } \\
\text { \& Behringer, 2008). }\end{array}$ \\
\hline Nest & $\begin{array}{l}\text { mouse } \\
\text { monoclonal }\end{array}$ & $1 / 400$ & $\begin{array}{l}\text { MAB1259 (R\&D } \\
\text { Systems) } \\
\text { RRID:AB_2251304 }\end{array}$ & $\begin{array}{l}\text { NSO mouse myeloma cell line transfected with huma } \\
\text { n Nestin }\end{array}$ \\
\hline Nest & $\begin{array}{l}\text { mouse } \\
\text { monoclonal }\end{array}$ & $1 / 500$ & $\begin{array}{l}\text { MAB353 clone rat- } \\
401 \text { (Millipore) } \\
\text { RRID:AB_94911 }\end{array}$ & Nestin purified from embryonic rat spinal cord \\
\hline Vimentin & $\begin{array}{l}\text { mouse } \\
\text { monoclonal }\end{array}$ & $1 / 300$ & $\begin{array}{l}\text { M0725 clone V9 } \\
\text { (Dako) } \\
\text { RRID:AB_10015203 }\end{array}$ & Purified vimentin from porcine eye lens \\
\hline Vimentin & $\begin{array}{l}\text { chicken } \\
\text { polyclonal }\end{array}$ & $1 / 500$ & $\begin{array}{l}\text { AB5733 (Millipore) } \\
\text { RRID:AB_11212377 }\end{array}$ & Recombinant Golden Syrian hamster vimentin \\
\hline & $\begin{array}{l}\text { rabbit } \\
\text { polyclonal }\end{array}$ & $1 / 500$ & $\begin{array}{l}\text { Z0334 (Dako) } \\
\text { RRID:AB_10013382 }\end{array}$ & GFAP isolated from cow spinal cord \\
\hline GFAP & $\begin{array}{l}\text { mouse } \\
\text { monoclonal }\end{array}$ & $1 / 500$ & $\begin{array}{l}\text { MAB3402 } \\
\text { (Chemicon) } \\
\text { RRID:AB_94844 }\end{array}$ & Purified glial filament \\
\hline GLAS & $\begin{array}{l}\text { rabbit } \\
\text { polyclonal }\end{array}$ & $1 / 300$ & $\begin{array}{l}\text { ab416 (Abcam) } \\
\text { RRID:AB_304334 }\end{array}$ & $\begin{array}{l}\text { Synthetic peptide corresponding to amino acids } 522- \\
541 \text { of rat EAAT1 (PYQLIAQDNEPEKPVADSET) }\end{array}$ \\
\hline Ki67 & $\begin{array}{l}\text { rabbit } \\
\text { polyclonal }\end{array}$ & $1 / 100$ & $\begin{array}{l}\text { ab15580 (Abcam) } \\
\text { RRID:AB_443209 }\end{array}$ & $\begin{array}{l}\text { Synthetic peptide conjugated to KLH corresponding } \\
\text { to amino acids } 1222-1234 \text { of human Ki67 (C- } \\
\text { EDLAGFKELFQTP). }\end{array}$ \\
\hline CD68 & $\begin{array}{l}\text { mouse } \\
\text { monoclonal }\end{array}$ & $1 / 300$ & $\begin{array}{l}\text { M0814 clone KP1 } \\
\text { (Dako) } \\
\text { RRID:AB_2314148 }\end{array}$ & Lysosomal fraction of human lung macrophages \\
\hline NeuN & $\begin{array}{l}\text { mouse } \\
\text { monoclonal }\end{array}$ & $1 / 300$ & $\begin{array}{l}\text { MAB377 } \\
\text { (Chemicon) } \\
\text { RRID:AB_2298772 } \\
\end{array}$ & Purified cell nuclei from mouse brain \\
\hline VI & $\begin{array}{l}\text { goat } \\
\text { polyclonal }\end{array}$ & $1 / 300$ & $\begin{array}{l}\text { Sc-21041 (Santa } \\
\text { Cruz) } \\
\text { RRID:AB_2273044 }\end{array}$ & $\begin{array}{l}\text { 16-Residue synthetic peptide representing the } \\
\text { carboxy-terminal domain of human VIP } \\
\text { from amino acids } 125-140\end{array}$ \\
\hline
\end{tabular}

†antibody used for immunostainings on human tissue; ${ }^{\ddagger}$ antibody used for immunostainings on rodent tissue. CD68, cluster of differentiation 68; EAAT1, Excitatory Amino Acid Transporter 1 (synonymous GLAST, Glutamate-Aspartate Transporter); GFAP, Glial Fibrillary Acidic Protein; NeuN, Neuronal Nuclei; Sox2, SRY (sex determining region Y)-box 2; VIP, Vasoactive intestinal peptide. ${ }^{\$}$ Based on liquid chromatography coupled to tandem mass spectrometry performed in this study. 
Table 2. Secondary antibodies used in the study.

\begin{tabular}{|l|l|l|l|}
\hline Species & Conjugated & Dilution & $\begin{array}{l}\text { Reference (Company) } \\
\text { RRID number }\end{array}$ \\
\hline Donkey anti-mouse IgG & Alexa 568 & $1 / 500$ & $\begin{array}{l}\text { A10037 (Molecular Probes) } \\
\text { RRID:AB_2534013 }\end{array}$ \\
\hline Donkey anti-mouse IgG & Alexa 488 & $1 / 500$ & $\begin{array}{l}\text { A21202 (Molecular Probes) } \\
\text { RRID:AB_141607 }\end{array}$ \\
\hline Donkey anti-rabbit IgG & Alexa 568 & $1 / 500$ & $\begin{array}{l}\text { A10042 (Molecular Probes) } \\
\text { RRID:AB_2534017 }\end{array}$ \\
\hline Donkey anti-rabbit IgG & Alexa 488 & $1 / 500$ & $\begin{array}{l}\text { A21206 (Molecular Probes) } \\
\text { RRID:AB_141708 }\end{array}$ \\
\hline Donkey anti-goat IgG & Alexa 568 & $1 / 500$ & $\begin{array}{l}\text { A11057 (Molecular Probes) } \\
\text { RRID:AB_142581 }\end{array}$ \\
\hline Donkey anti-goat IgG & Alexa 647 & $1 / 500$ & $\begin{array}{l}\text { A21447 (Molecular Probes) } \\
\text { RRID:AB_141844 }\end{array}$ \\
\hline Donkey anti-chicken IgG & Alexa 488 & $1 / 500$ & $\begin{array}{l}\text { 703-545-155 (Jackson Immunoresearch) } \\
\text { RRID:AB_2340375 }\end{array}$ \\
\hline
\end{tabular}

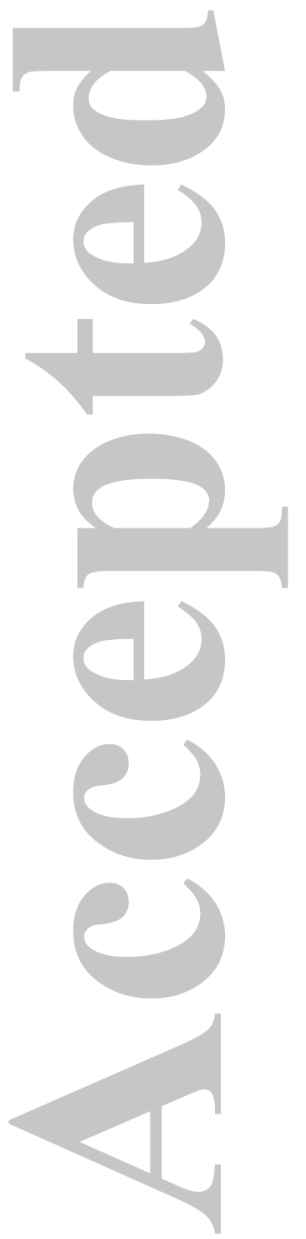


Table 3. Summary of the expression of NPC markers in the adult human hypothalamus,

SVZ, parenchyma and hippocampal dentate gyrus.

\begin{tabular}{|c|c|c|c|c|c|c|c|c|c|c|c|c|c|c|}
\hline & \multicolumn{6}{|c|}{ Hypothalamus } & \multicolumn{4}{|c|}{ sVZ } & \multicolumn{2}{|c|}{ Parenchyma } & \multicolumn{2}{|c|}{ Dentate gyrus } \\
\hline & $\begin{array}{c}\text { ependy } \\
\text { mal } \\
\text { cells }\end{array}$ & gap & $\begin{array}{l}\text { ribbon } \\
\text { cells }\end{array}$ & buds & $\begin{array}{l}\text { tany } \\
\text { cytes }\end{array}$ & SCh & $\begin{array}{c}\text { ependy } \\
\text { mal } \\
\text { cells }^{\dagger}\end{array}$ & gap & $\begin{array}{c}\text { ribbon } \\
\text { cells }\end{array}$ & buds & $\begin{array}{l}\text { endothe } \\
\text { lial cells }\end{array}$ & $\begin{array}{c}\text { astro } \\
\text { cytes } \\
\ddagger\end{array}$ & $\begin{array}{l}\text { endothe } \\
\text { lial cells }\end{array}$ & $\begin{array}{c}\text { astro } \\
\text { cytes } \\
\ddagger\end{array}$ \\
\hline Sox 2 & $\begin{array}{c}+ \\
(84.5 \pm \\
2.3 \%) \\
\end{array}$ & + & $\begin{array}{c}+ \\
(29.0 \pm \\
5.4 \%) \\
\end{array}$ & $\begin{array}{c}+ \\
(58.3 \pm \\
6.1 \%) \\
\end{array}$ & + & \begin{tabular}{|c|}
+ \\
$(30.6 \pm$ \\
$4.0 \%)$ \\
\end{tabular} & + & + & + & + & - & - & - & - \\
\hline nestin & $\begin{array}{c}+ \\
(38.1 \pm \\
4.1 \%) \\
\end{array}$ & + & $\begin{array}{c}+ \\
(37.0 \pm \\
3.7 \%) \\
\end{array}$ & $\begin{array}{c}+ \\
(67.7 \pm \\
4.9 \%) \\
\end{array}$ & + & \begin{tabular}{|c|}
+ \\
$(16.4 \pm$ \\
$1.3 \%)$ \\
\end{tabular} & +/-- & + & + & + & + & - & + & - \\
\hline vimentin & $\begin{array}{c}+ \\
(83.6 \pm \\
3.8 \%) \\
\end{array}$ & + & $\begin{array}{c}+ \\
(49.0 \pm \\
2.7 \%) \\
\end{array}$ & $\begin{array}{c}+ \\
(57.6 \pm \\
5.7 \%) \\
\end{array}$ & + & \begin{tabular}{|c|}
+ \\
$(38.8 \pm$ \\
$3.4 \%)$ \\
\end{tabular} & $++/-$ & + & + & + & + & $+/-$ & + & $+/-$ \\
\hline GLAST & $\begin{array}{c}+ \\
(97.1 \pm \\
0.7 \%) \\
\end{array}$ & ++ & $\begin{array}{c}+ \\
(80.6 \pm \\
3.6 \%) \\
\end{array}$ & $\begin{array}{c}+ \\
(97.6 \pm \\
1.1 \%) \\
\end{array}$ & + & \begin{tabular}{|c|}
+ \\
$(28.0 \pm$ \\
$7.5 \%)$ \\
\end{tabular} & + & ++ & + & + & - & $+/-$ & - & - \\
\hline GFAP & $\begin{array}{c}+ \\
(60.9 \pm \\
8.0 \%)\end{array}$ & ++ & $\begin{array}{c}+ \\
(78.0 \pm \\
9.5 \%)\end{array}$ & $\begin{array}{c}+ \\
(92.6 \pm \\
3.0 \%)\end{array}$ & + & $\begin{array}{c}+ \\
(42.7 \pm \\
13.0 \%)\end{array}$ & $+/-$ & ++ & + & + & - & + & - & + \\
\hline
\end{tabular}

${ }^{\dagger}$ Ependymal cells that line the lateral ventricles are more rarely nestin-immunoreactive (+/--) but show higher vimentin immunoreactivity (++/-) compared to ependymal cells of the third ventricle. ${ }^{\ddagger}$ In the parenchyma lying behind the hypocellular gap of the third and lateral ventricles, and in the hippocampal dentate gyrus, vimentin and/or GLAST are detected in small stellate cells at a lower frequency than GFAP-positive cells $(+/-)$, suggesting that they are expressed by subpopulations of astrocytes. SCh, suprachiasmatic nucleus; SVZ, subventricular zone of the lateral ventricles. Quantification of the stainings in the hypothalamus is given as mean \pm SEM.

Table 4. Summary of the expression of NPC markers in the adult hypothalamus of the mouse, rat and grey mouse lemur.

\begin{tabular}{|c|c|c|c|c|c|c|c|c|c|c|c|c|}
\hline & \multicolumn{4}{|c|}{ Mouse hypothalamus } & \multicolumn{4}{|c|}{ rat hypothalamus } & \multicolumn{4}{|c|}{ Mouse lemur hypothalamus } \\
\hline & $\begin{array}{c}\text { ependy } \\
\text { mal cells }\end{array}$ & $\begin{array}{l}\text { tany } \\
\text { cytes }\end{array}$ & $\begin{array}{l}\text { parenchy } \\
\text { mal cells }\end{array}$ & $\begin{array}{l}\text { endothe } \\
\text { lial cells }\end{array}$ & $\begin{array}{l}\text { ependy } \\
\text { mal cells }\end{array}$ & $\begin{array}{l}\text { tany } \\
\text { cytes }\end{array}$ & $\begin{array}{l}\text { parenchy } \\
\text { mal cells }\end{array}$ & $\begin{array}{l}\text { endothe } \\
\text { lial cells }\end{array}$ & $\begin{array}{c}\text { ependy } \\
\text { mal cells }\end{array}$ & $\begin{array}{l}\text { tany } \\
\text { cytes }\end{array}$ & $\begin{array}{l}\text { parenchy } \\
\text { mal cells }\end{array}$ & $\begin{array}{l}\text { endothe } \\
\text { lial cells }\end{array}$ \\
\hline Sox 2 & + & + & + & - & + & + & + & - & + & + & + & - \\
\hline nestin & $+\operatorname{rare}^{\dagger}$ & + & - & $+/-$ & $+\operatorname{rare}^{\dagger}$ & + & - & + & NA & NA & NA & NA \\
\hline vimentin & + & + & - & $+1-$ & + & + & + rare $^{\ddagger}$ & + & + & + & + rare $^{\ddagger}$ & + \\
\hline
\end{tabular}


${ }^{\dagger}$ Most ependymal cells showed low to undetectable nestin labeling. The rare ependymal cells with marked, unambiguous nestin immunoreactivity were scattered or gathered at varying dorso-ventral and antero-posterior locations along the third ventricular border. ${ }^{\ddagger}$ Occasional small vimentin-positive stellate cells were detected in the parenchyma surrounding the dorsal part of the third ventricle. NA, not available.
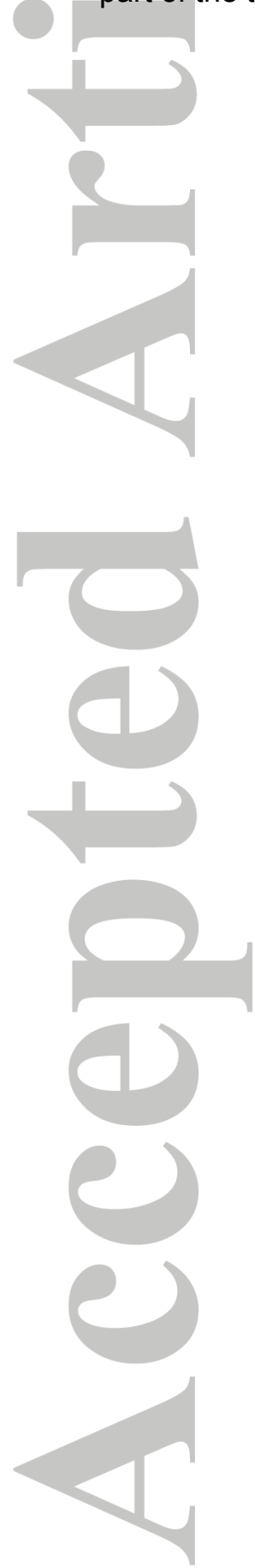


\section{Figure legends}

Figure 1. Characterization of the specificity of antibodies used to detect NPC markers in human tissues. a-g: Expression of Sox2 (a, magenta, stained with the goat polyclonal \# sc17320 from Santa Cruz), Ki67 (b, magenta), vimentin (c, green, stained with the mouse monoclonal M0725 clone V9 from Dako), GLAST (d, green), nestin (e, green) and GFAP (f, magenta, stained with the rabbit polyclonal Z0334 from Dako) in the cerebral cortex of a 11week-old human fetus. All markers are detected in radial glial cells, which have their cell body lining the ventricle (LV) and extend a long process across the nervous tissue toward the pial surface (top left corner, not visible). Note the co-localisation of nestin and GFAP in radial glial cells (g, merge). h: Expression of nestin in an adult human GBM. i, j: Double immunofluorescent labeling using two different anti-Sox2 antibodies (i, magenta: goat polyclonal \# sc-17320 from Santa Cruz; j, green: mouse monoclonal \# ab79351 from Abcam) in the adult human hypothalamus yielded the same expression profile. Arrowheads point to examples of double-labeled cells. $\mathbf{k}$, I: Double immunofluorescent labeling using two different anti-GFAP antibodies (k, green: mouse monoclonal MAB3402 from Chemicon; I, magenta: rabbit polyclonal Z0334 from Dako) in the adult human SVZ yielded the same expression profile. Nuclei were counterstained with Hoechst (all panels except g, blue). 3V, third ventricle; CP, cortical plate; IZ, intermediate zone; LV, lateral ventricle; SVZ, subventricular zone; VZ, ventricular zone. Scale bars $=50 \mu \mathrm{m}$ in a-g, k, l; $20 \mu \mathrm{m}$ in h, i, j.

Figure 2. Representative coronal histological sections stained with Toluidine Blue across the rostro-caudal extent of the human hypothalamus. a: anterior-most region containing the preoptic recess of the third ventricle. b: anterior hypothalamic area. c, d: tuberal region. e: mammillary region. $3 \mathrm{~V}$, third ventricle; ac, anterior commissure; $\mathrm{DMH}$, dorsomedial hypothalamic nucleus; FLV, frontal horn of lateral ventricle; fx, fornix; Inf, infundibular nucleus (or arcuate nucleus of the hypothalamus); InfS, infundibular stalk; IthA, interthalamic adhesion; LT, lamina terminalis; ME, median eminence; ML, medial mammillary nucleus, 
lateral part; MM, medial mammillary nucleus, medial part; MPO, medial preoptic nucleus; opt, optic tract; oc, optic chiasm; P3V, preoptic recess of the third ventricle; $\mathrm{Pa}$, paraventricular nucleus; PaPo, paraventricular hypothalamic nucleus, posterior part; $\mathrm{PH}$, posterior hypothalamic area; PV, paraventricular thalamic nucleus; SCh, suprachiasmatic nucleus; SO, supraoptic nucleus; VMH, ventromedial hypothalamic nucleus. Scale bar $=2 \mathrm{~mm}$.

Figure 3. Expression of nestin and Sox 2 along the wall of the human third ventricle. a: Lowmagnification photomontage of Hoechst counterstaining (grey) showing the third ventricle border at an antero-posterior level corresponding to the end of the anterior hypothalamic area and the beginning of the tuberal region. $\mathbf{a}_{1}-\mathbf{h}$ : Double immunofluorescent labeling of nestin (green) and Sox2 (magenta). Nuclei were counterstained with Hoechst (blue). $\mathbf{a}_{1}-\mathbf{a}_{4}$ : High-magnification images of the areas indicated in a. Insets in $a_{1}, a_{2}$ : High-magnification images of the boxed areas. Most of the third ventricular border is lined by a ribbon of small nestin/Sox2 double-labeled cells with multiple processes (arrows in $a_{1}, a_{2}, b, c, d$ ) separated from the ependymal layer by a hypocellular gap ( $G$, double arrow in $\left.a_{1}, a_{3}, b, c, d\right)$. These cells cohabit with Sox2-positive/nestin-negative cells (arrowheads in $a_{1}, a_{2}$ ). Some nestin/Sox2 double-labeled cells in the ribbon extend long processes (crossed arrow) to contact ependymal cells (inset in b) or capillaries (g). The nestin-positive subependymal area shows occasional thickenings $\left(a_{2}, a_{3}\right)$ that can protrude into the ventricle $\left(a_{4}, g, h\right)$. Protrusions are associated with an interruption of the ependymal layer (open arrowheads). Empty arrows point to invaginations of Sox2-positive/nestin-negative ependymal cells in the underlying parenchyma forming rosettes (b, c, d, e) or crowns (f). Regular invaginations of ependymal cells associated with bulging of the wall gives the border a crenelated aspect (b, c). Asterisks indicate nestin-positive capillaries. 3V, third ventricle; ep, ependymal layer; G, hypocellular gap. Scale bars $=1 \mathrm{~mm}$ in $\mathrm{a} ; 50 \mu \mathrm{m}$ in $\mathrm{a}_{1}, \mathrm{a}_{2}, \mathrm{a}_{3}, \mathrm{a}_{4}, \mathrm{~b}, \mathrm{c}, \mathrm{d}, \mathrm{f}, \mathrm{h} ; 20 \mu \mathrm{m}$ in e, g and insets. 
Figure 4. Expression of NPC markers in ependymal and ribbon cells of the human third ventricle. Nestin (green) and Sox2 (magenta) were co-immunodetected with vimentin (a, c, d, f, g, white), GLAST (h, j, k, m, n, white) or GFAP (o, q, r, t, u, white). The ependymal layer (ep) and gap (G) are shown at higher magnification in upper right panels (b-d, i-k, p-r) while the ribbon $(\mathrm{rb})$ is shown at higher magnification in lower right panels (e-g, I-n, s-u). Plain arrowheads show ependymal cells that co-express nestin, Sox2 and vimentin, GLAST or GFAP. While GLAST was strongly detected in most ependymal cells $(h)$, vimentin showed highly variable expression levels (a). Some ependymal cells showed low levels of vimentin in their soma (a-d, empty arrowheads) but prominent expression in their basal processes, some of which co-expressed nestin (crossed arrows in b-d). Ependymal cells were heterogeneous for the expression of GFAP, with GFAP-negative ( $q$, empty arrowhead) next to GFAPpositive cells (q, plain arrowhead). Note the strong expression of GLAST (h, j) and GFAP (o, q) in the hypocellular gap. Arrows point to ribbon cells that co-express nestin, Sox2 and vimentin, GLAST or GFAP. The same cells are pointed in main panels $(a, h, o)$ and highmagnification views. Empty arrows in main panels point to vimentin- (a), GLAST- (h) and GFAP-expressing cells (o) in the parenchyma behind the ribbon. Stars indicate capillaries whose endothelial cells express vimentin (a) but lack GLAST (h) and GFAP (o). Nuclei were counterstained with Hoechst (blue). 3V, third ventricle; ep, ependymal layer; G, hypocellular gap; rb, ribbon. Scale bars $=50 \mu \mathrm{m}$ in a, h, o; $20 \mu \mathrm{m}$ in all other panels.

Figure 5. Expression of NPC markers in ventricular protrusions of the human third ventricle. Protrusions of various sizes and forms are found all along the third ventricle. The continuous ependymal layer (plain arrowheads) is interrupted on top of the protrusions (empty arrowheads). These structures contain nestin (a-i, green)/Sox2 (magenta)-immunoreactive cells that co-express vimentin (a-c, j-l), GLAST (d-f) and GFAP (g-i) (arrows, co-expressing cells are shown at higher magnification in insets). The subependymal region and buds are devoid of NeuN-immunoreactive cells, which are found in the deeper parenchyma (j-I, white, 
crossed arrow). Nuclei were counterstained with Hoechst (blue). 3V, third ventricle; P3V, preoptic recess of the third ventricle. Scale bars $=50 \mu \mathrm{m}$ in main panels and $20 \mu \mathrm{m}$ in insets.

Figure 6. Expression of NPC markers in the median eminence of the human hypothalamus. a: Nestin (green) and Sox2 (magenta) are expressed in tanycytes, which line the floor of the third ventricle. Crossed arrows point to tanycyte nuclei and arrows show tanycyte processes. b-d: co-immunodetection of nestin (green) and vimentin (b, white), GLAST (c, white) or GFAP (d, white). The three panels below each main panel show a high magnification view of the boxed area. Nestin-immunoreactive tanycyte processes co-express vimentin (b, arrow), GLAST (c, arrow) and GFAP (d, arrow). White arrowheads point to nestin-positive processes devoid of vimentin (b), GLAST (c) or GFAP (d) immunoreactivity. Vimentin-positive (b, empty arrowhead) and GFAP-positive (d, empty arrowhead) processes devoid of nestin immunoreactivity were also seen. Nuclei were counterstained with Hoechst (blue, panel a). $3 \mathrm{~V}$, third ventricle, ME, median eminence. Scale bars $=50 \mu \mathrm{m}$ in a, $20 \mu \mathrm{m}$ in other panels.

Figure 7. Expression of NPC markers in the human suprachiasmatic nucleus. a: Immunofluorescent staining of VIP (white) was performed to ascertain the correct localization of the suprachiasmatic nucleus on human hypothalamus sections. Crossed arrows point to VIP-immunoreactive neurons. b: Double immunofluorescent staining of nestin (green) and Sox2 (magenta). The inset is a high-magnification view of the boxed area in the main panel. Note the co-existence of small process-bearing nestin/Sox2 co-expressing cells (arrows) with Sox2-positive/nestin-negative cells (arrowheads). c-k: triple immunofluorescent stainings of nestin (green), Sox2 (magenta) and vimentin (white, d, e), GLAST (white, g, h) or GFAP (white, j, k). Arrows point to triple labelled cells and arrowheads show nestin-negative/Sox2positive cells. I, m: Co-immunodetection of GLAST (green), Sox2 (magenta) and NeuN (white) in the human suprachiasmatic nucleus. Empty arrows point to NeuN-positive neurons that lack GLAST and Sox2 expression. The arrow shows a GLAST/Sox2 co-expressing cell devoid of NeuN. Nuclei were counterstained with Hoechst (blue). P3V, preoptic recess of the 
third ventricle; SCh, suprachiasmatic nucleus. Scale bars $=50 \mu \mathrm{m}$ in a, b; $20 \mu \mathrm{m}$ in c-m and inset in $b$.

Figure 8. Proliferation along the wall of the human third ventricle. a-e: Co-immunofluorescent staining of nestin (green), Sox2 (magenta) (a, b, d) and Ki67 (c, e, white). The 2 cells pointed by the arrows in the main panel (a) are shown at higher magnification in the panels b-e. Very rare nestin/Sox2-co-expressing cells were immunoreactive for Ki67 (arrows). The empty arrow in d-e shows a nestin/Sox2-co-expressing cell devoid of Ki67 immunolabeling. Arrowheads in b-e point to Ki67-positive cells that do not co-express nestin and Sox2. $\mathbf{f}$-h: Co-immunofluorescent staining of Ki67 (white) and CD68 (green) reveals the presence of double-labeled cells (arrow) in addition to Ki67-positive/CD68-negative cells (plain arrowheads) and Ki67-negative/CD68-positive cells (empty arrowhead). Note that Ki67positive cells often appear as pairs of closely apposed cells (arrow), a picture suggestive of a recent mitotic event. Nuclei were counterstained with Hoechst (blue). $3 \mathrm{~V}$, third ventricle; ep, ependymal layer. Scale bars $=50 \mu \mathrm{m}$ in a, $20 \mu \mathrm{m}$ in b-h.

Figure 9. Expression of NPC markers along the third ventricle of the mouse (a-h), rat (i-k) and grey mouse lemur (l-q). Representative photographs were taken at the level of the tuberal region of the hypothalamus. The rat third ventricle is shown as a whole while the third ventricle from the mouse and grey mouse lemur is shown in its most dorsal (a-d, I-n) and ventral (e-h, o-q) portions. Co-immunostainings of Sox2 (magenta, a, e, i, l, o), nestin (green, $b, f, j$ ) and vimentin (white, $c, g$, inset in $j, m, p$ ). Merge images of all but hoechst stainings are shown in $d, h, k, n, q$. In the dorsal part of the third ventricle, ependymal cells co-express Sox2 and vimentin (empty arrowheads, a-d, i-k, I-n) with very occasional nestin co-labeling (a-d, white arrowhead). In the ventral part of the third ventricle, dorsal (arrow $\alpha$ ) and ventral (arrow $\beta$ ) tanycytes co-express Sox2, nestin and vimentin. While the third ventricle wall is composed by a regular layer of ependymal cells in the mouse $(a, e)$ and grey mouse lemur (l, o), that of the rat shows thickenings frequently protruding inside the ventricle (crossed arrows 
in i). The yellow asterisk in $p$ shows a capillary wrapped by tanycyte processes. Note that both tanycyte processes and endothelial cells are vimentin-immunoreactive (see Fig. 10j for examples of vimentin-positive capillaries). Nuclei were counterstained with Hoechst (blue, a, e, i, l, o). 3V, third ventricle; Arc, arcuate nucleus; ME, median eminence; PT, pars tuberalis. Scale bars $=50 \mu \mathrm{m}$.

Figure 10. Expression of NPC markers in the suprachiasmatic nucleus of the mouse (a-d), rat (e-h) and grey mouse lemur (i-k). A high density of Sox2-expressing cells (magenta) is detected in the suprachiasmatic nucleus of all three species $(a, e, i)$. In the mouse, the suprachiasmatic nucleus is devoid of vimentin (b) and nestin (d) immunoreactivity. In the rat, it also lacks vimentin expression (h) but contains nestin-immunoreactive capillaries (f, $g$, arrows with stars). In both species, the third ventricle ependymal layer (empty arrowheads) expresses Sox2, vimentin but shows low to undetectable levels of nestin. In the grey mouse lemur, the suprachiasmatic nucleus contains rare vimentin-immunoreactive elements that do not co-express Sox2 (arrows with stars in j, k point to capillary sections; arrows in i-k show Sox2-immunonegative/vimentin-positive cells). The mouse lemur third ventricle is lined by Sox2 and vimentin-immunoreactive ependymal cells (i-k, empty arrowheads). Nuclei were counterstained with Hoechst (a, c, e, g, i, k, blue). 3V, third ventricle; oc, optic chiasm; SCh, suprachiasmatic nucleus. Scale bars $=50 \mu \mathrm{m}$.

Figure 11. Expression of NPC markers in the human SVZ. a-d: Double immunofluorescent staining of nestin (green) and Sox2 (magenta) in the SVZ showing the ribbon (rb) of nestin/Sox2-co-expressing cells (arrows), separated from the ependymal layer (arrowheads) by the hypocellular gap (G). e-h: Vimentin (white) is expressed in ependymal cells (plain arrowheads), ribbon cells (arrows) and parenchymal astrocytes (crossed arrows in e). Note the variable levels of vimentin expression in ependymal cells, some of which express low to undetectable levels of the protein (empty arrowheads). The ribbon contains a population of cells that co-express nestin, Sox2 and vimentin (arrows, f-h). i-I: GLAST (white) is expressed 
in ependymal cells (arrowheads) and is enriched in the gap and ribbon. The ribbon contains a population of cells that co-express nestin, Sox2 and GLAST (arrows, j-I). m-p: GFAP (white) is enriched in the gap and ribbon. The ribbon contains a population of cells that coexpress nestin, Sox2 and GFAP (arrows, n-p). GFAP is also expressed in parenchymal astrocytes (crossed arrows in $\mathrm{m}$ ) but is absent from most ependymal cells (empty arrowheads). Rare ependymal cells express GFAP (plain arrowhead, n-p). Nuclei were counterstained with Hoechst (blue). Microphotographs representative of the ventral (a-d, f-h, $\mathrm{i}-\mathrm{I}, \mathrm{n}-\mathrm{p})$ and dorsal $(\mathrm{e}, \mathrm{m}) \mathrm{SVZ}$. LV, lateral ventricle. Scale bars $=50 \mu \mathrm{m}$.

Figure 12. Expression of NPC markers in the dentate gyrus of the human hippocampus. a: Double immunofluorescent staining of nestin (green) and Sox2 (magenta). In the dentate gyrus, Sox2 was not detected and nestin was restricted to capillaries (asterisks). Note that Sox2 and nestin were readily detectable along the ventricular border of the temporal horn of the lateral ventricle on the same section (inset). Arrows point to nestin/Sox2 co-expressing cells; the arrowhead points to Sox2-positive/nestin-negative ependymal cells. b: Immunodetection of GFAP (white) reveals the presence of numerous astrocytes (arrows). c: Vimentin immunoreactivity (white) was detected in capillaries (asterisks) and small stellate cells (arrows). Nuclei were counterstained with Hoechst (blue). DG, dentate gyrus. LV, lateral ventricle. Scale bars $=50 \mu \mathrm{m}$. 


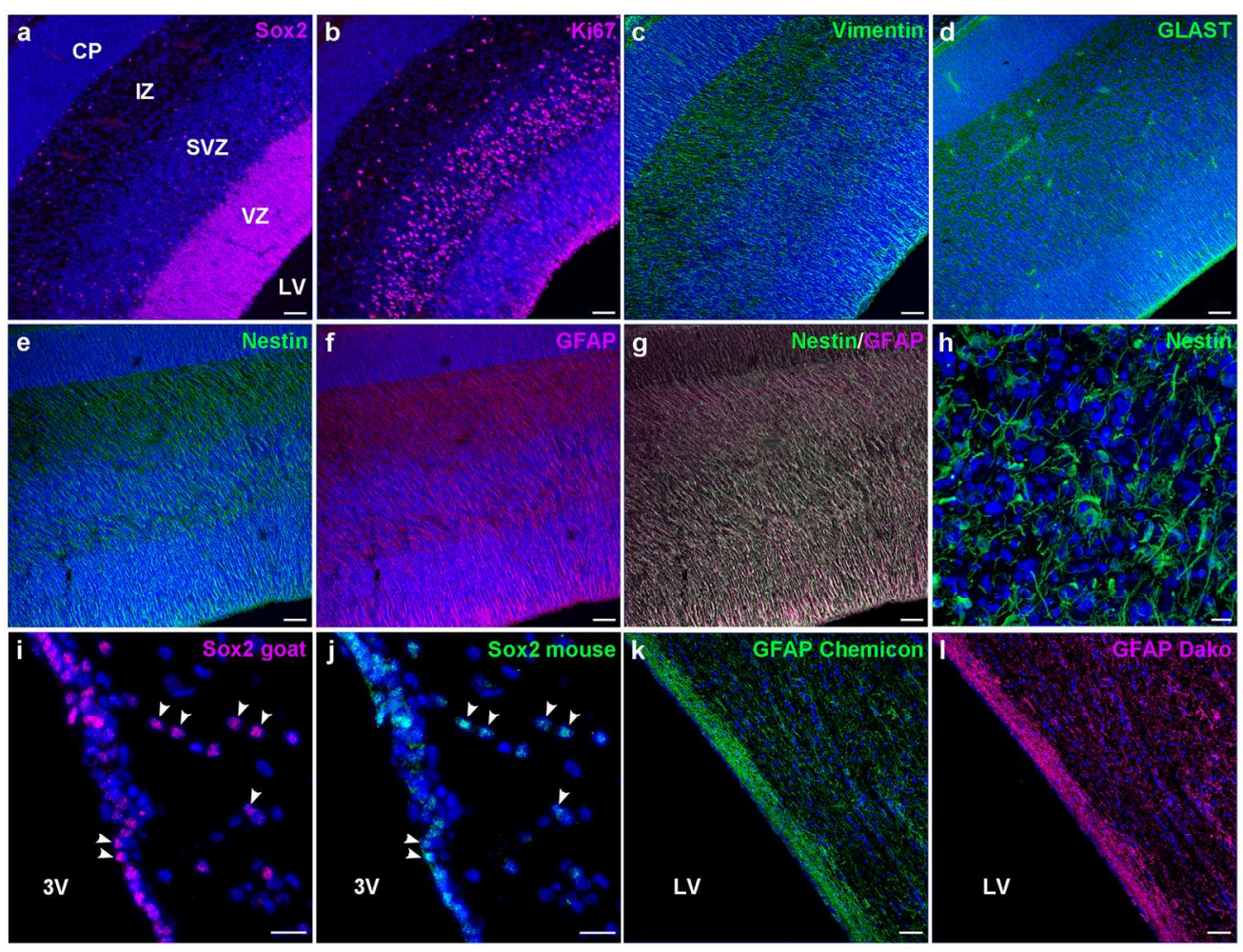

$171 \times 130 \mathrm{~mm}(300 \times 300 \mathrm{DPI})$

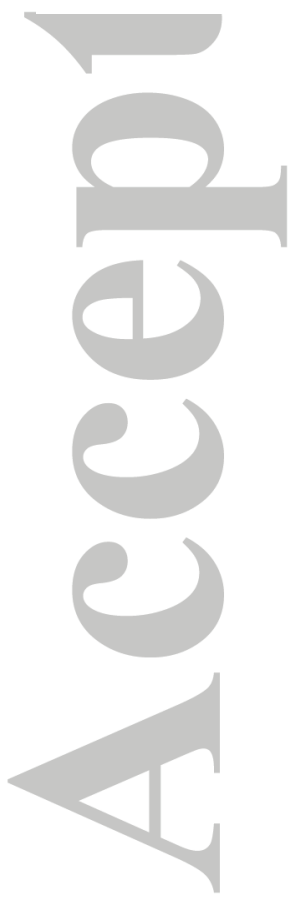




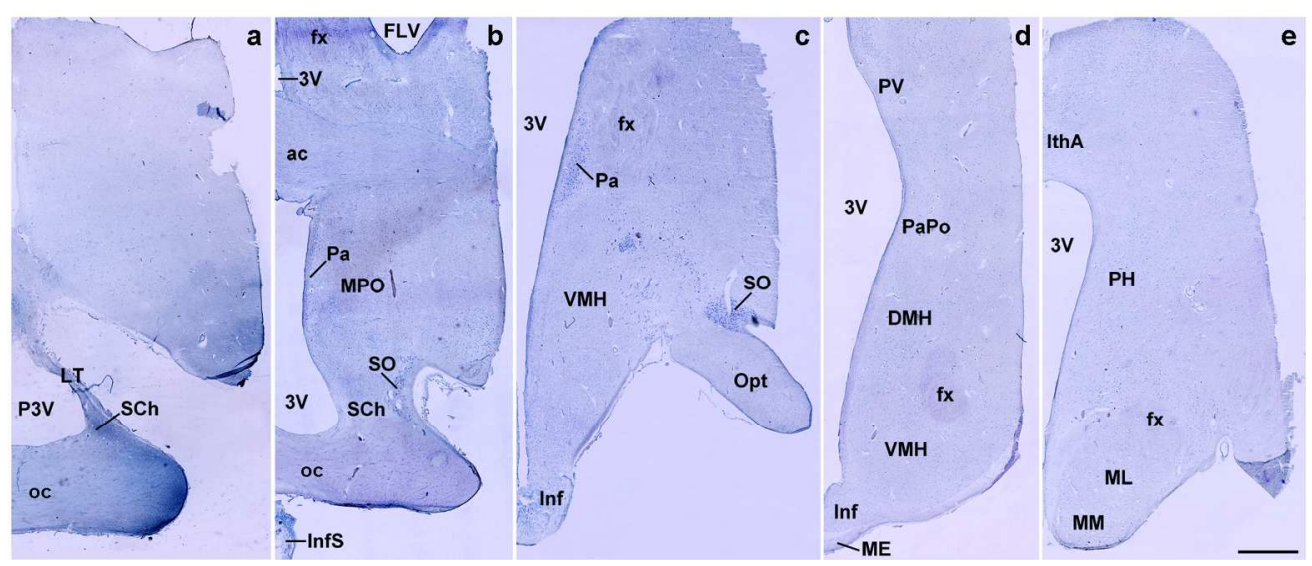

$<$

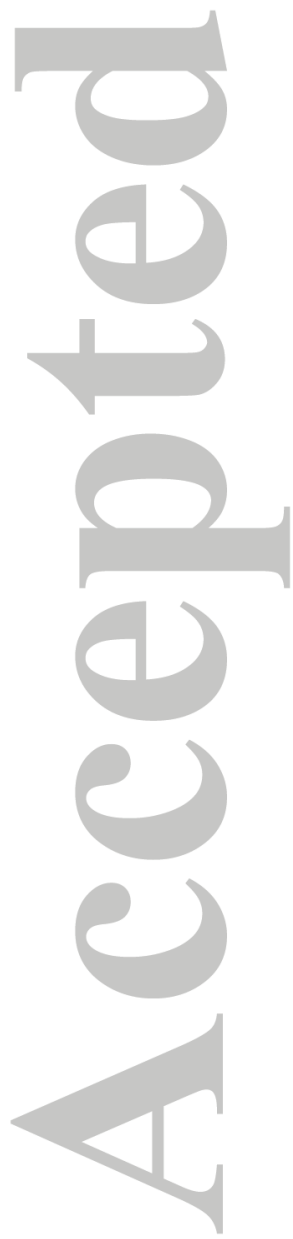




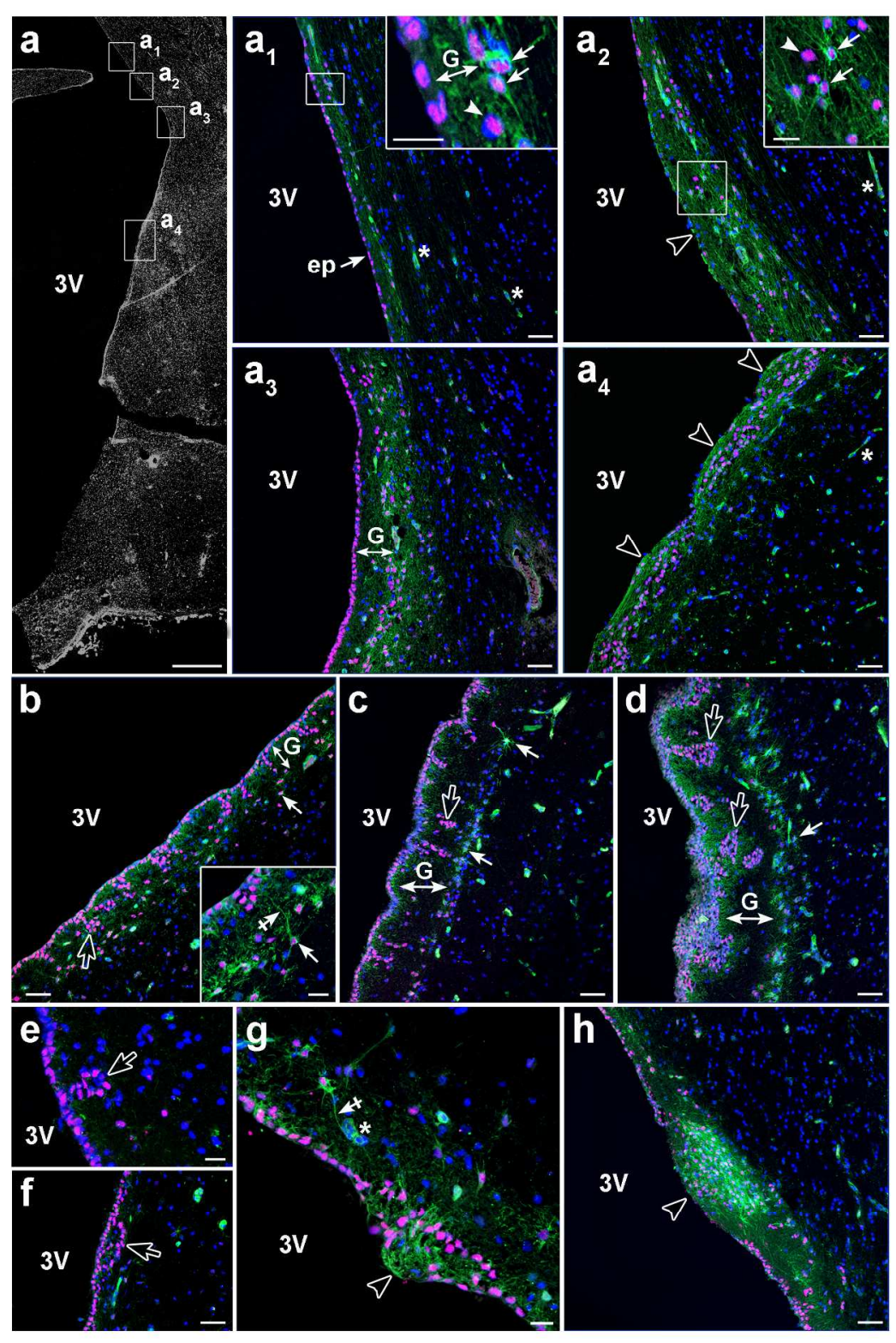

Fig. 3

$171 \times 254 \mathrm{~mm}(300 \times 300$ DPI $)$ 

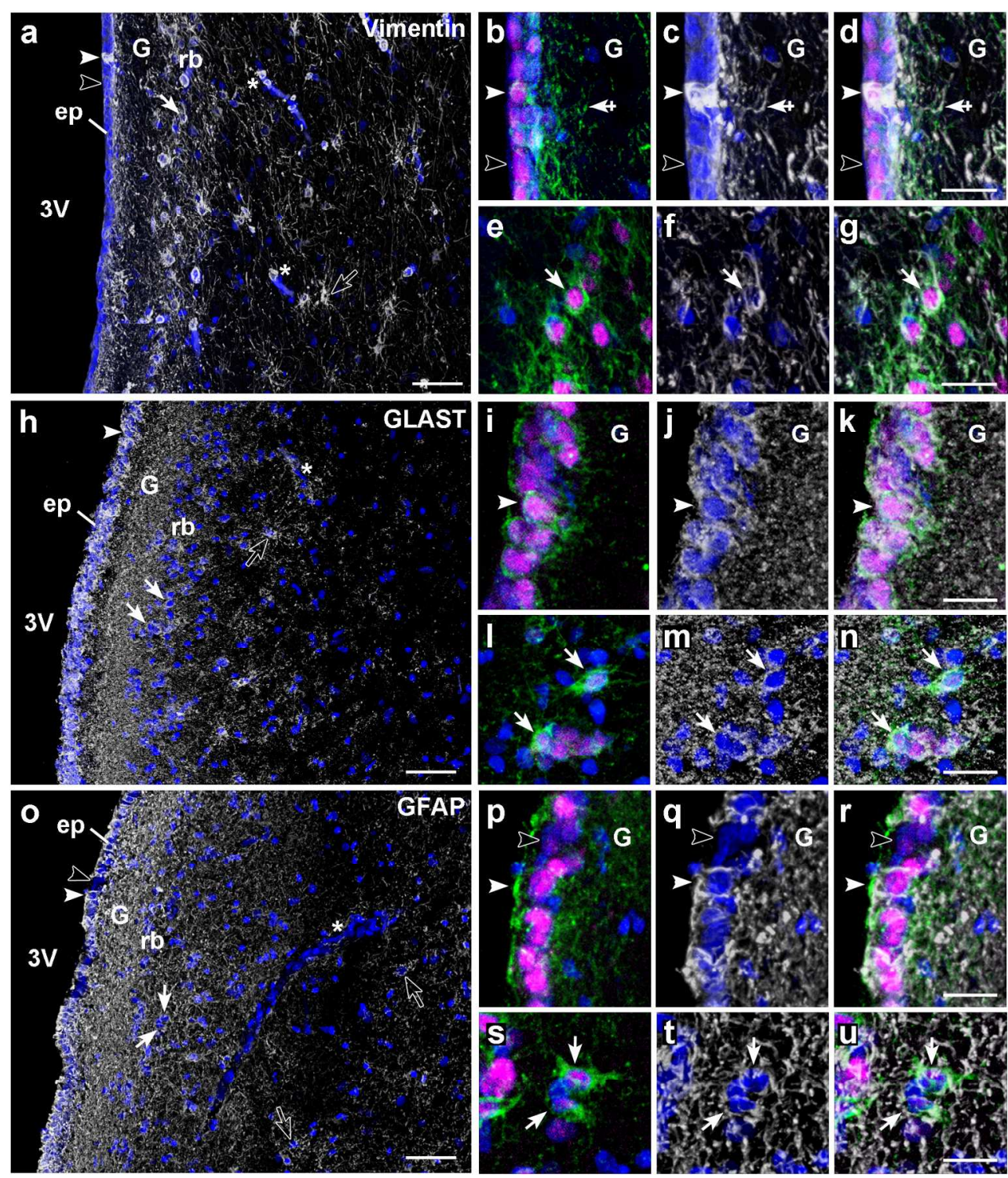

$171 \times 198 \mathrm{~mm}(300 \times 300 \mathrm{DPI})$

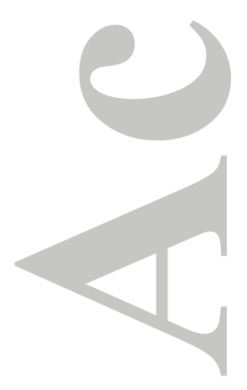




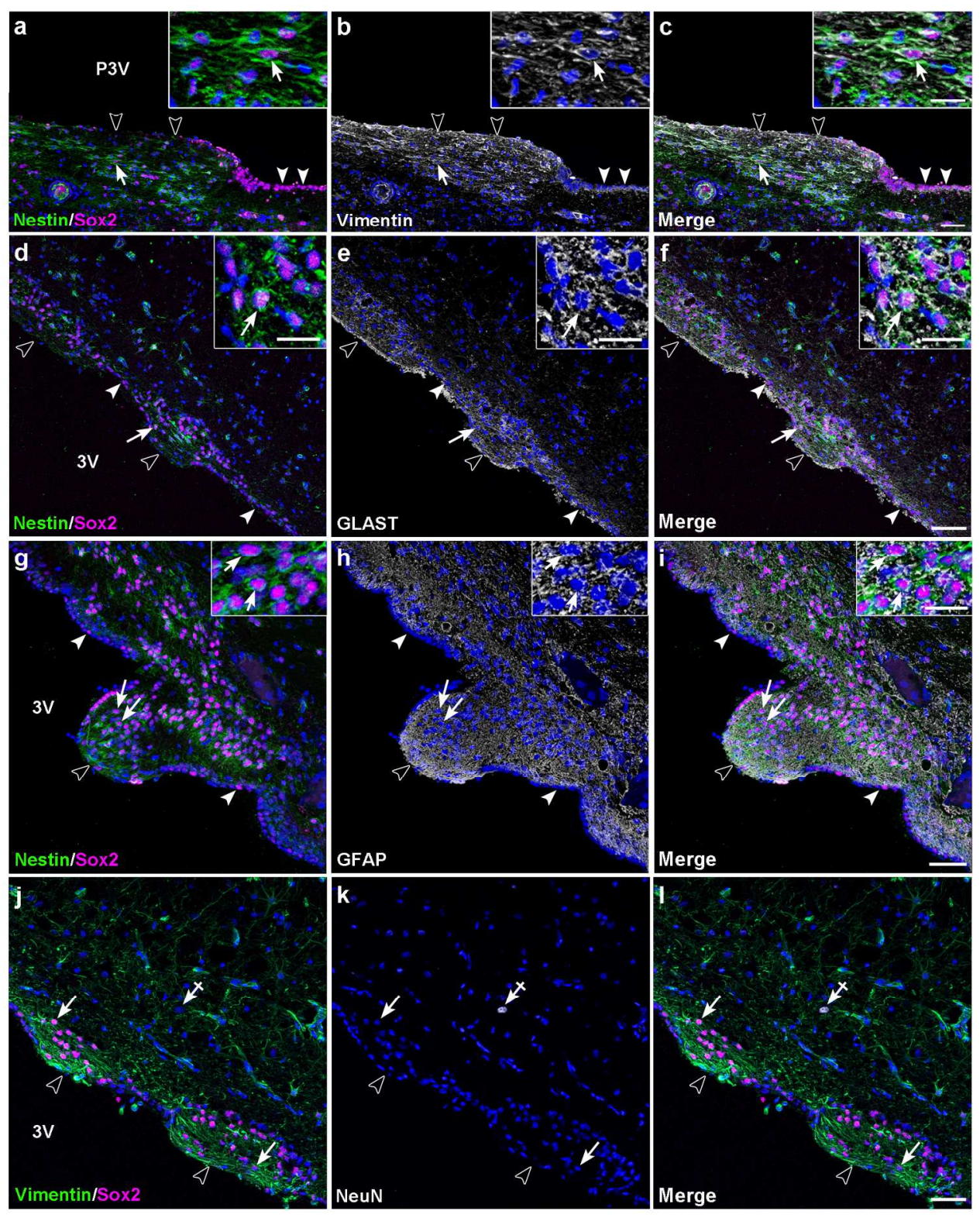

$171 \times 213 \mathrm{~mm}(300 \times 300 \mathrm{DPI})$

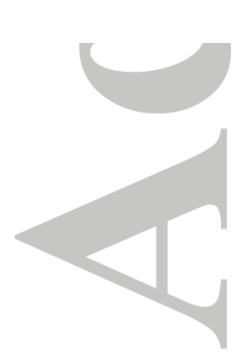



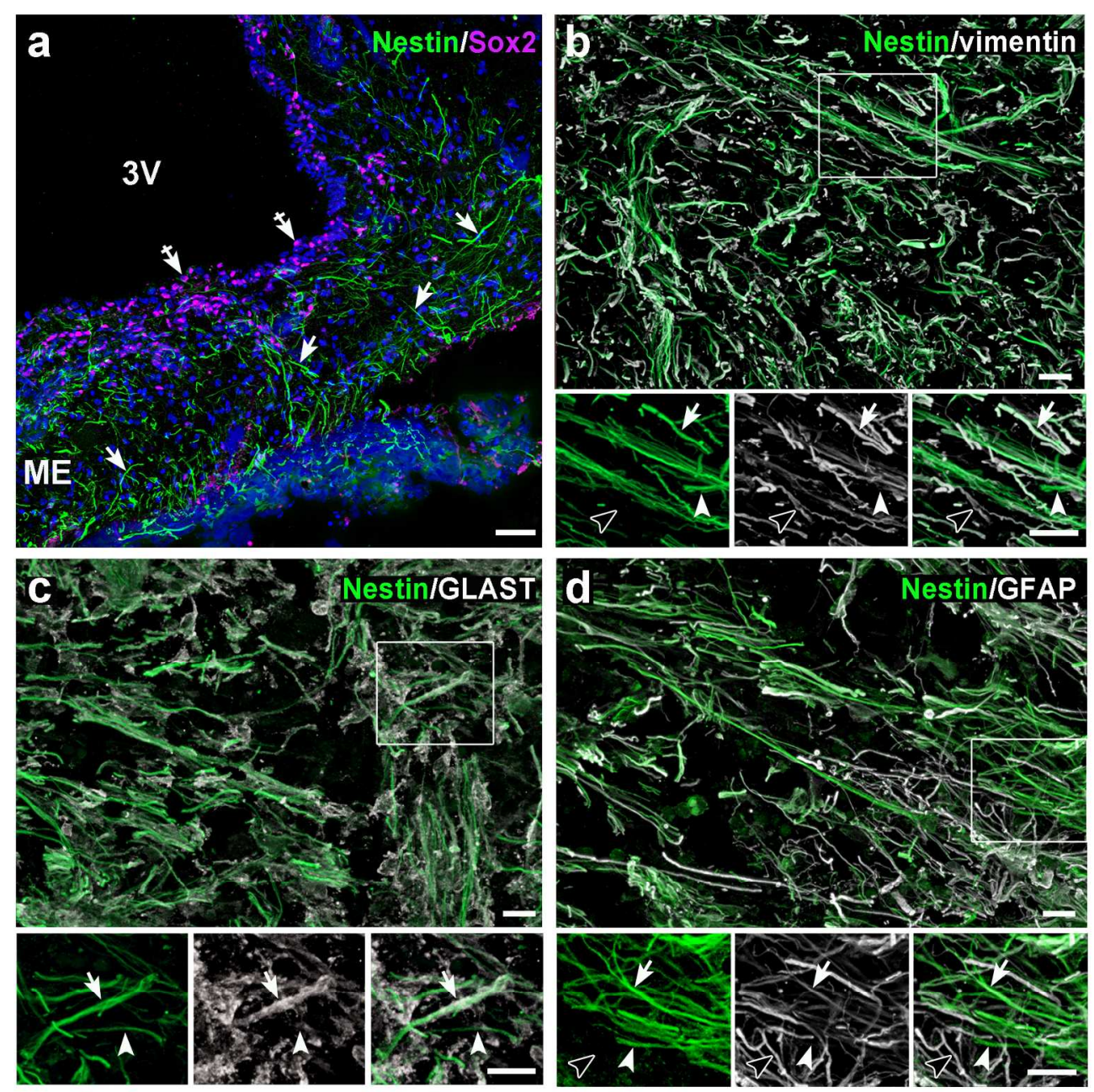

$171 \times 172 \mathrm{~mm}(300 \times 300 \mathrm{DPI})$

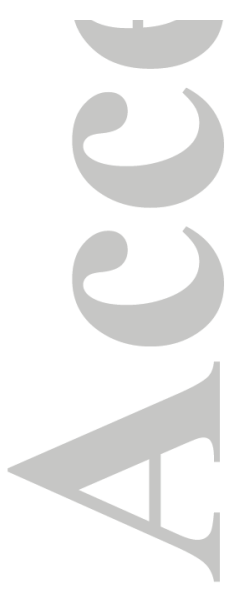

$171 \times 172 \mathrm{~mm}(300 \times 300 \mathrm{DPI})$ 


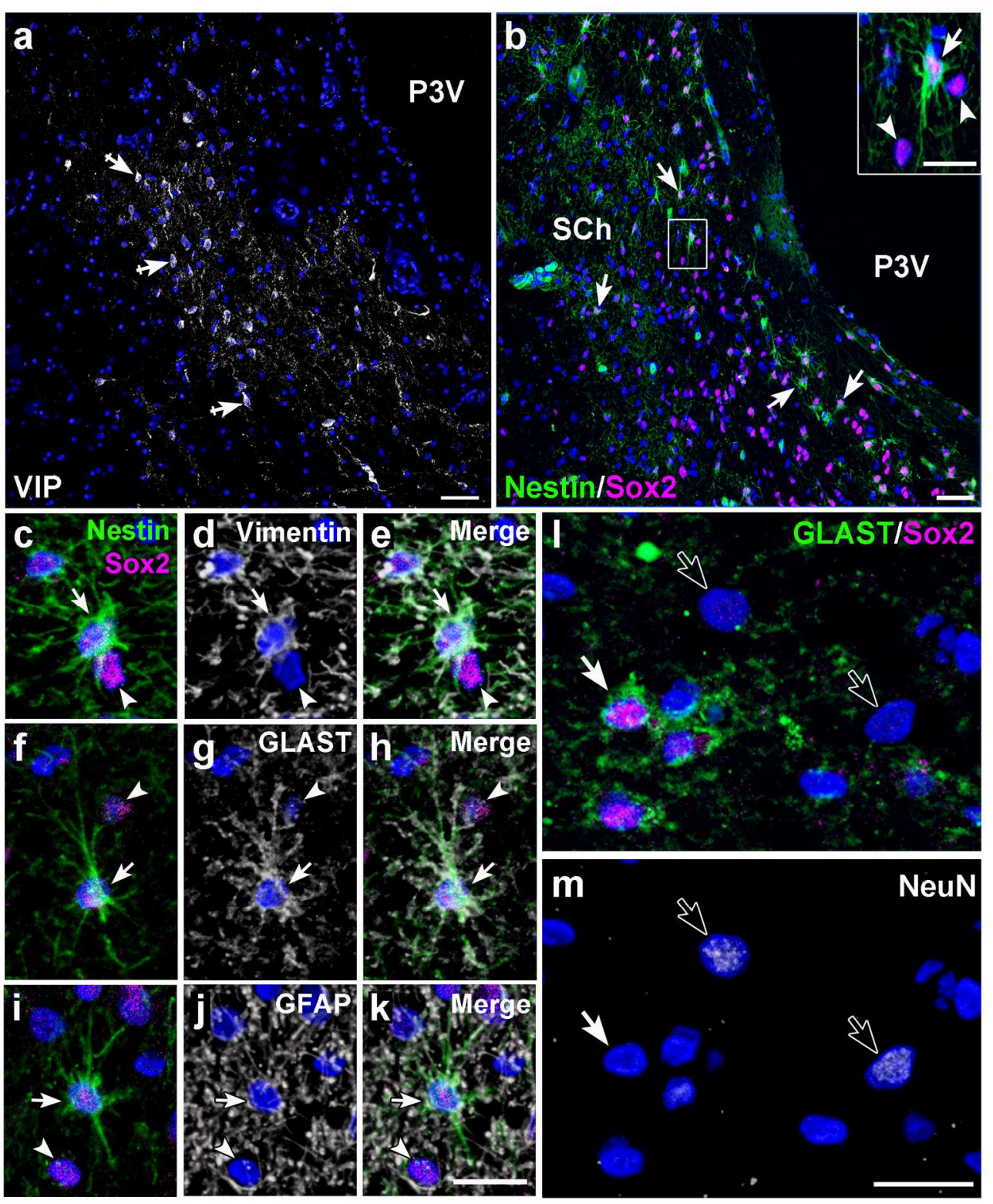

$171 \times 205 \mathrm{~mm}(300 \times 300 \mathrm{DPI})$

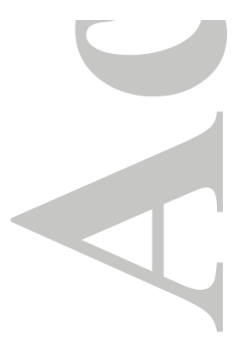




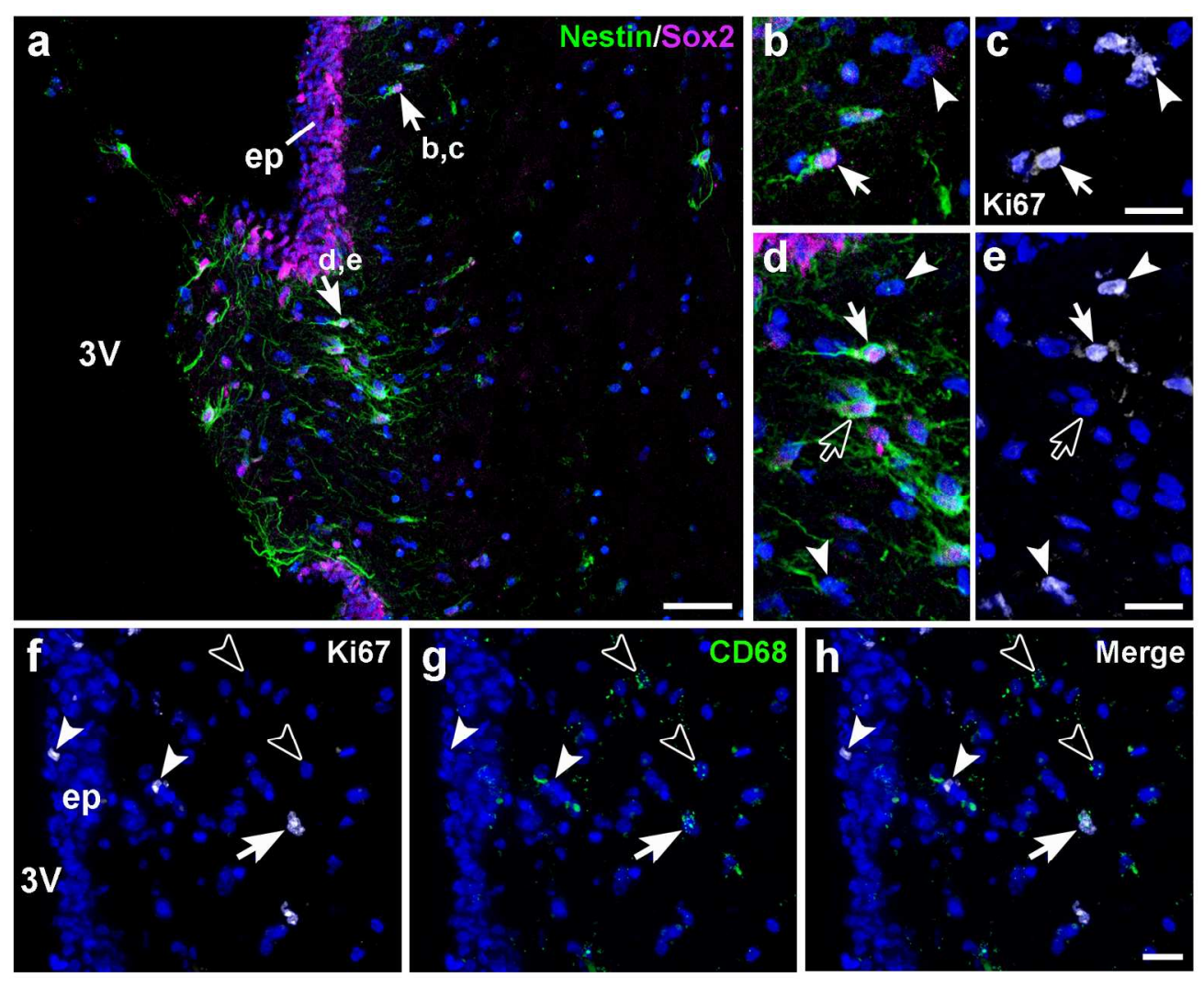

$171 \times 139 \mathrm{~mm}(300 \times 300 \mathrm{DPI})$

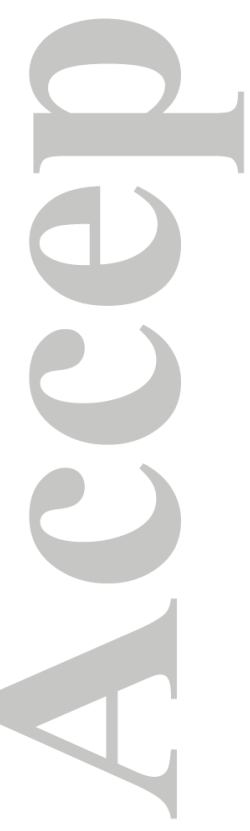




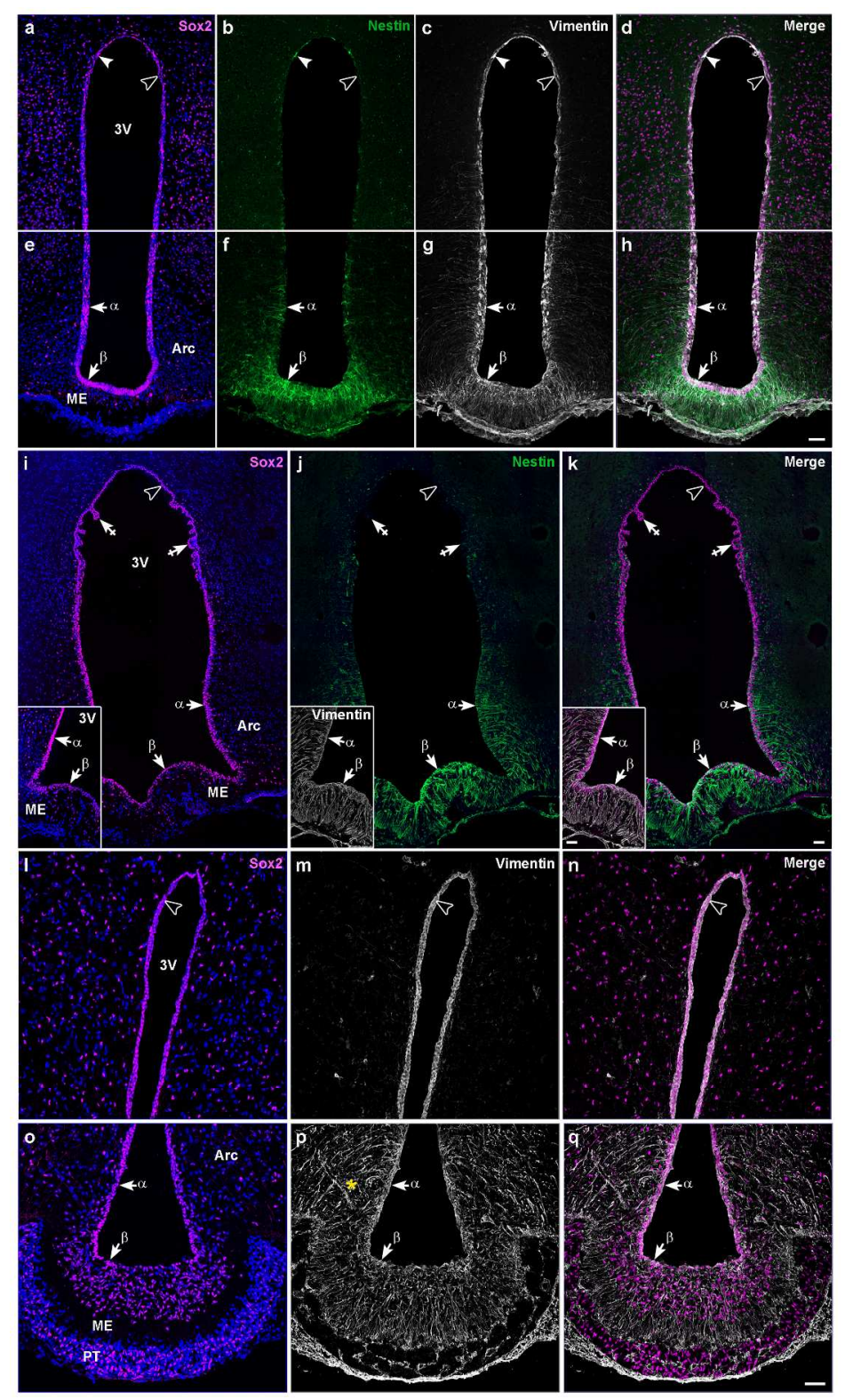

Fig. 9

$171 \times 288 \mathrm{~mm}(300 \times 300 \mathrm{DPI})$

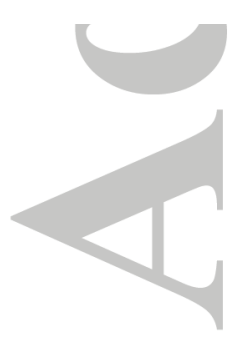




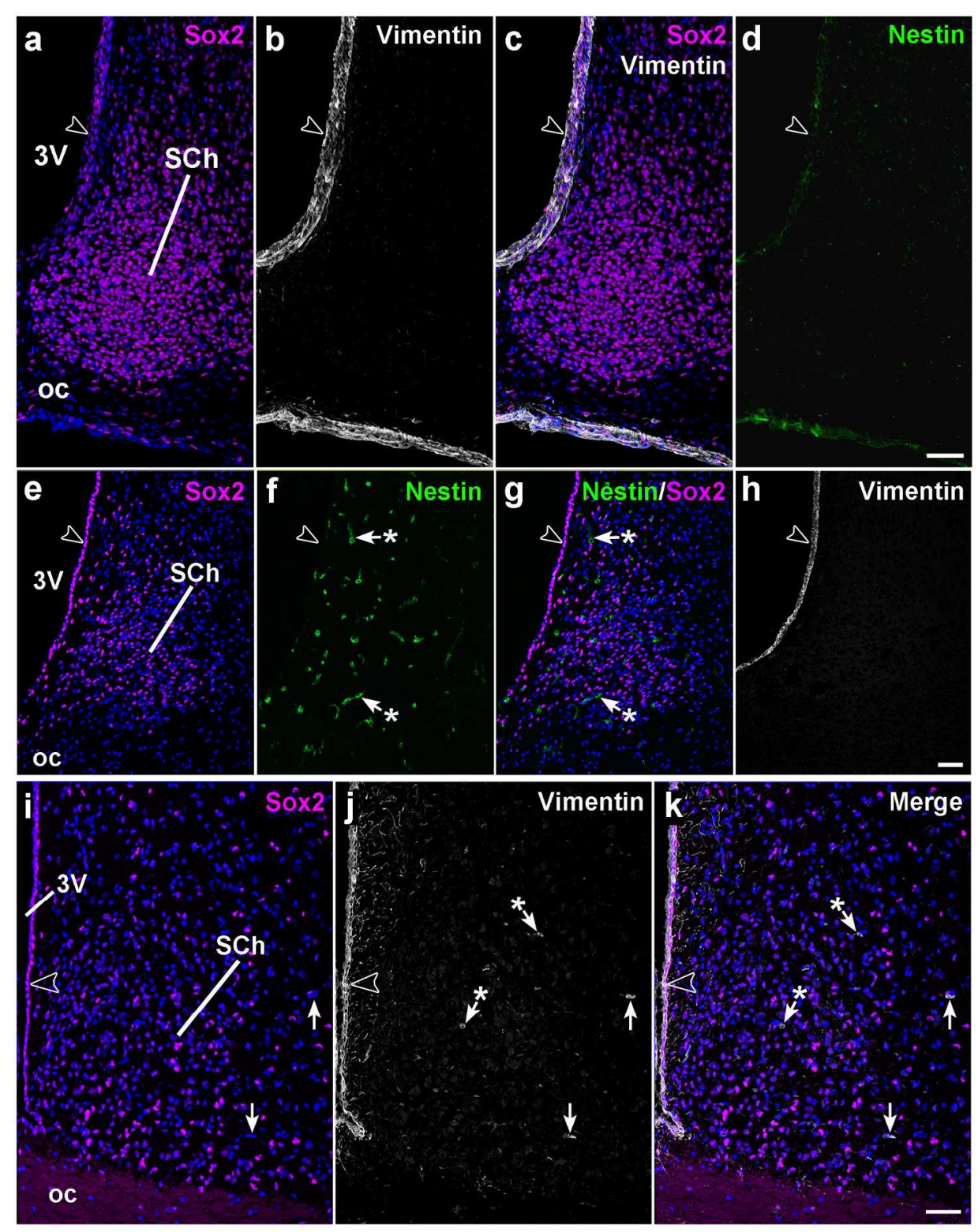

$171 \times 216 \mathrm{~mm}(300 \times 300 \mathrm{DPI})$

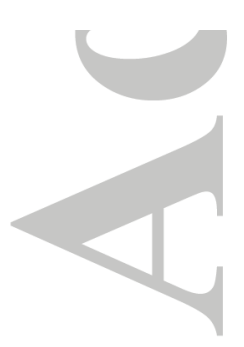




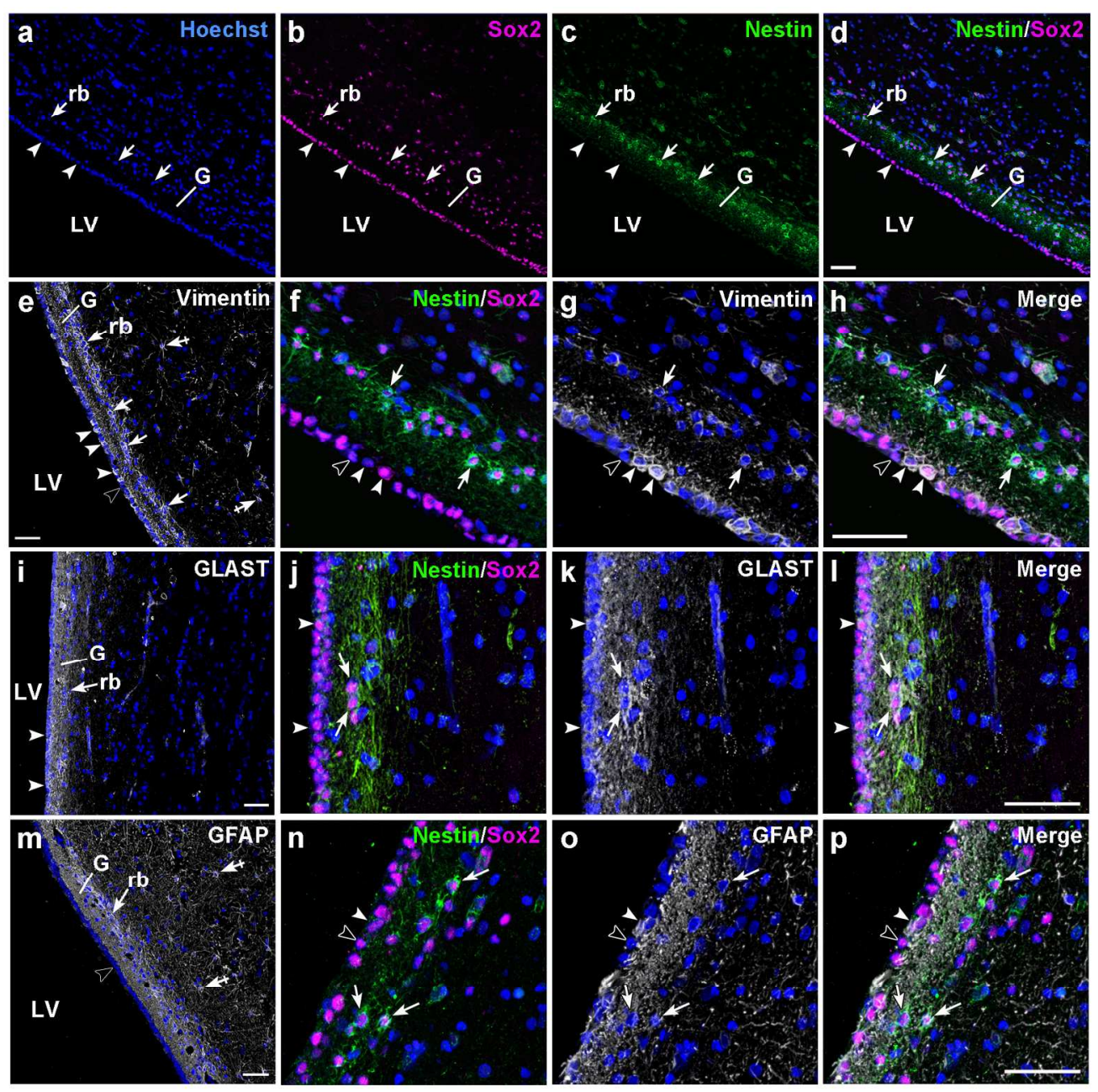

$171 \times 170 \mathrm{~mm}(300 \times 300 \mathrm{DPI})$

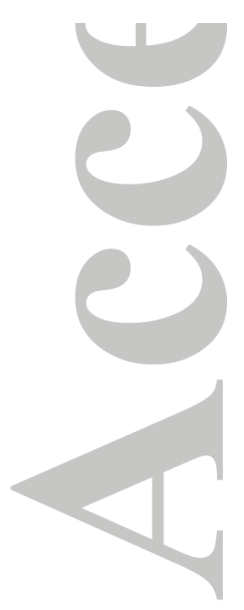




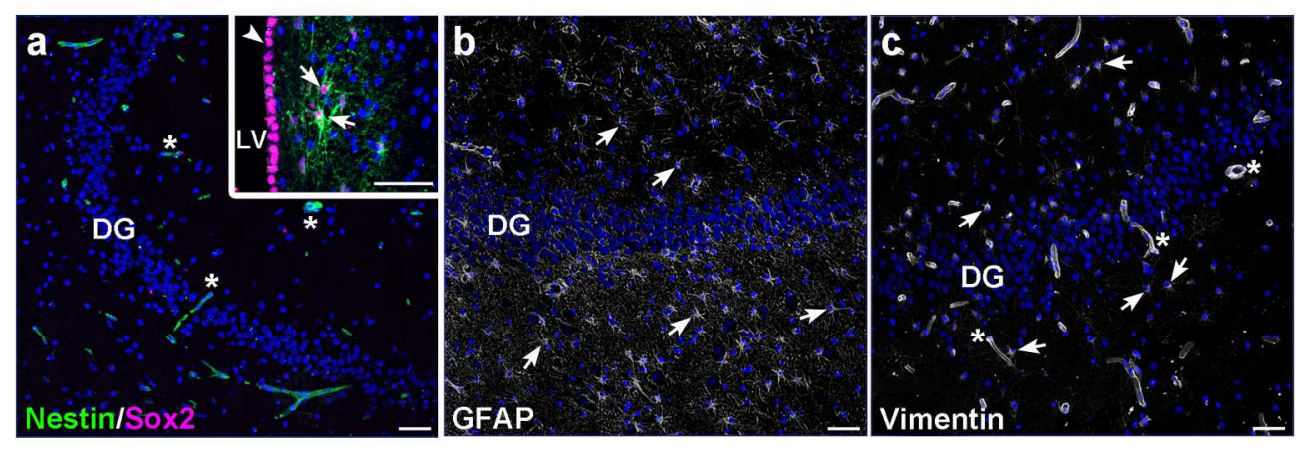

$171 \times 58 \mathrm{~mm}(300 \times 300 \mathrm{DPI})$
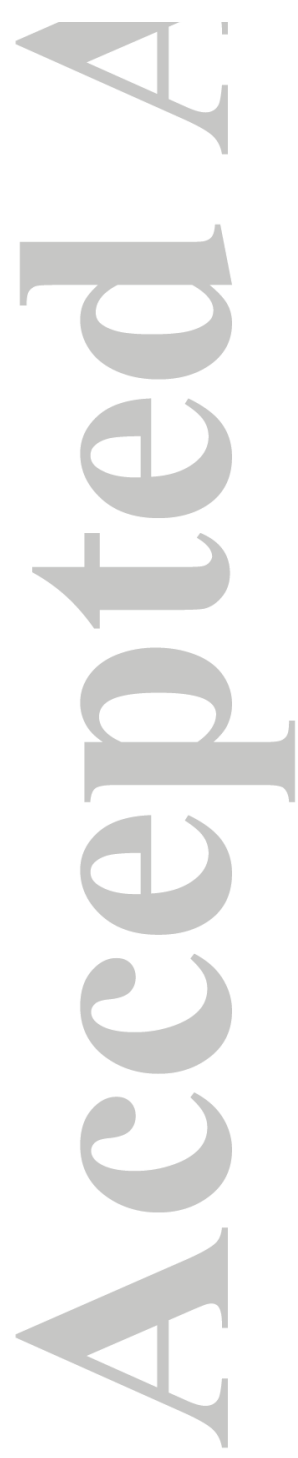


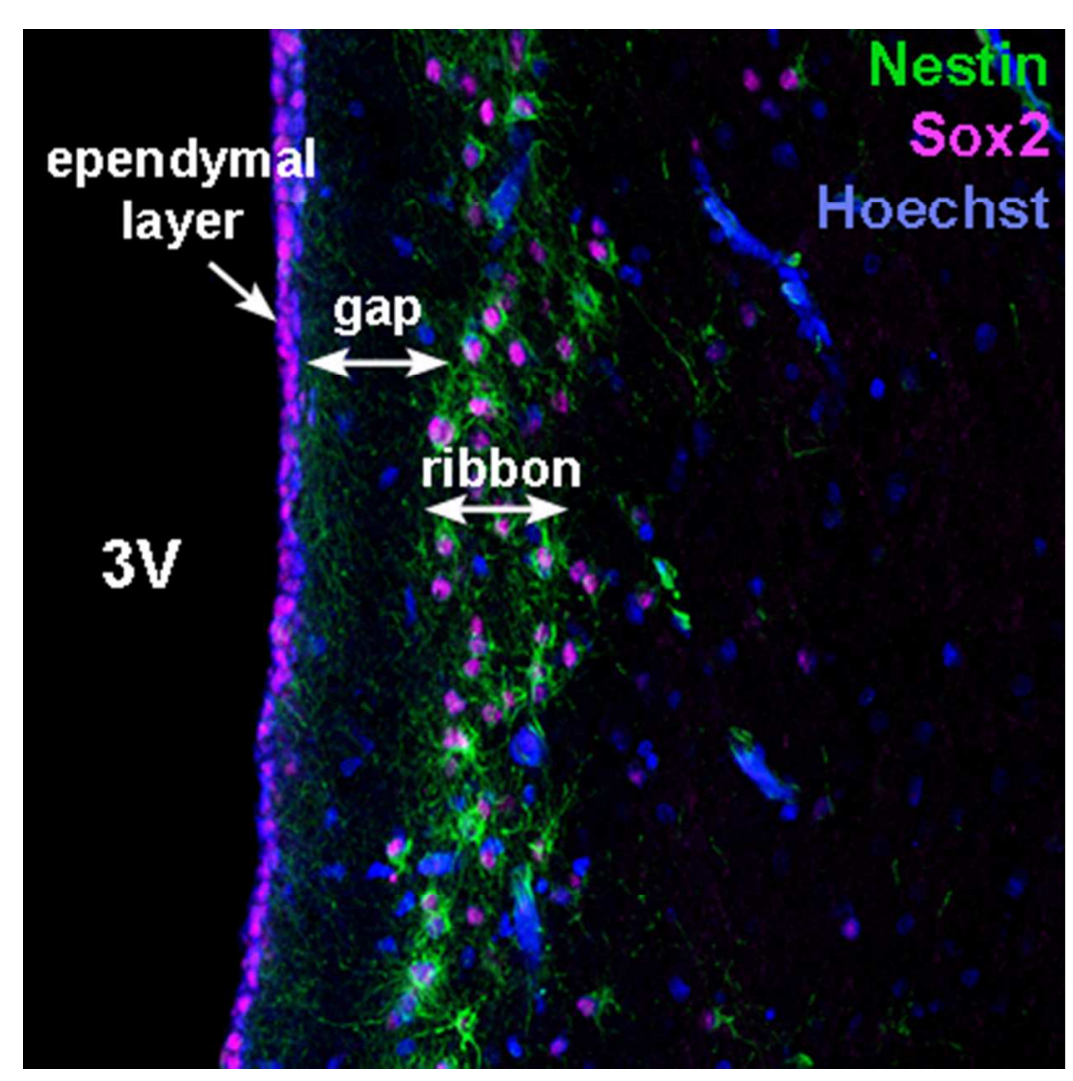

$141 \times 140 \mathrm{~mm}(72 \times 72$ DPI $)$

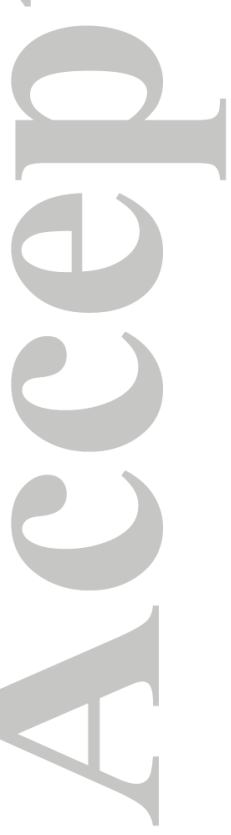


The adult human hypothalamus contains four populations of cells harbouring an antigenic profile of neural stem cells: ependymal cells, a ventricular ribbon of cells lying behind a hypocellular gap, tanycytes and a population of suprachiasmatic cells. In the mouse, rat and grey mouse lemur hypothalamus, a similar antigenic profile is essentially restricted to tanycytes.
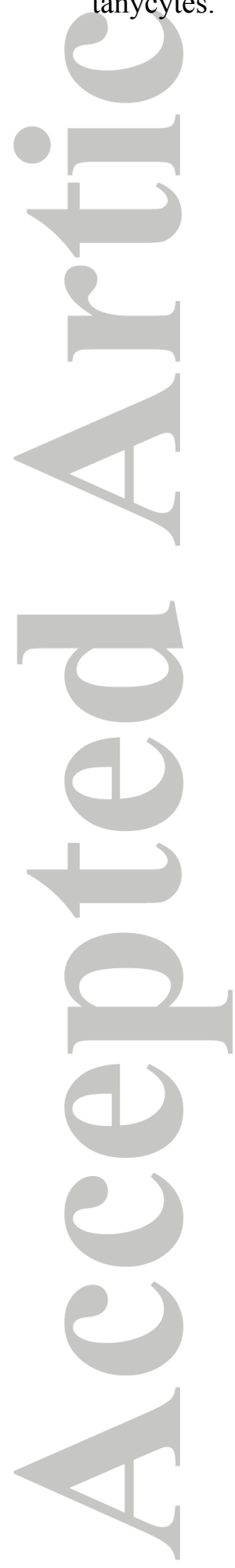